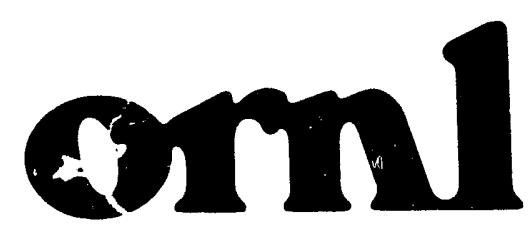

OAK RIDGE

NATIONAL

LABORATORY

MARTIN MARIETHA

ORNL/M-1327

\section{Active Sites Environmental Monitoring Program: FY 1990 Report}

\author{
D. S. Wickliff \\ C. M. Morrissey \\ T. L. Ashwood
}

Environmental Sciences Division

Publication No. 3615

\section{MANAGED BY}

MARTIN MARIETTA ENERGY SYSTEMS, INC.

FOR THE UNITED STATES

DEPARTMENT OF ENERGY

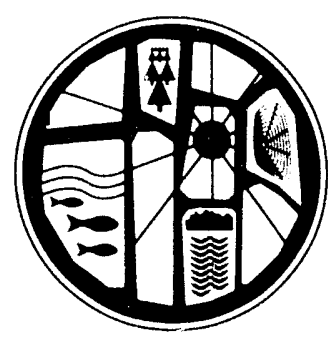


This repori has been reproduced directly from the best available copy.

Available to DOE and DOE contractors from the Office of Scientific and Technical Information, P.O. Box 62, Oak Ridge, TN 37831; prices available from (615) 576-8401, FTS 626-8401.

Available to the public from the National Technical Information Service, U.S. Department of Commerce, 5285 Port Royal Rd., Springfield, VA 22161.

This report was prepared as an account of work sponsored by an agency of the United States Governm.ent. Neither the United States Government nor any agency thereof, nor any of their employees, makes any warranty, express or implied, or assumes any legal liability or responsibility for the accuracy, completenese, or usefulness of any information, apparatus, product, or process disclosed, or represents that its use would not infringe privately owned rights. Reference herein to any specific commercial product, process, or service by trade name, trademark, manufacturer, or otherwise, does not necessarily constitute or imply its endorsement, recommendation, or favoring by the United States Government or any agency thereof. The views and opinions of authors expressed herein do not necessarily state or reflect those of the United States Government or any agency thereof. 


\title{
ACTIVE SITES ENVIRONMENTAL MONITORING PROGRAM: \\ FY 1990 ANNUAL REPORT
}

\author{
D. S. Wickliff, C. M. Morrissey, and T. L. Ashwood
}

Environmental Sciences Division

Publication No. 3615

Manuscript Completed: October 1990

Date Published: October 1991

Prepared for

Office of Defense Waste and Environmental Restoration

(EW 3010010 )

\author{
Prepared by the \\ OAK RIDGE NATIONAL LABORATORY \\ Oak Ridge, Tennessee 3\%831 \\ managed by \\ MARTIN MARIETTA ENERGY SYSTEMS \\ for the \\ U.S. DEPARTMENT OF ENERGY \\ under contract DE-AC05-84OR21400
}




\section{CONTENTS}

Page

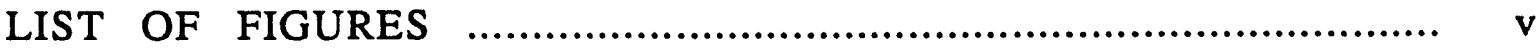

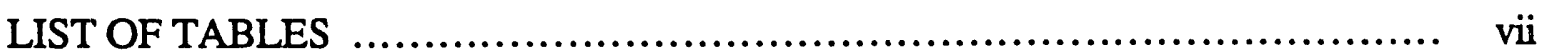

ABBREVIATIONS AND ACRONYMS ....................................... ix

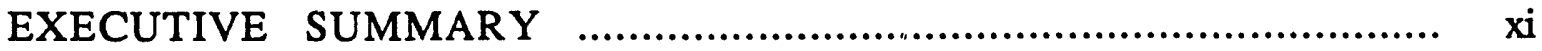

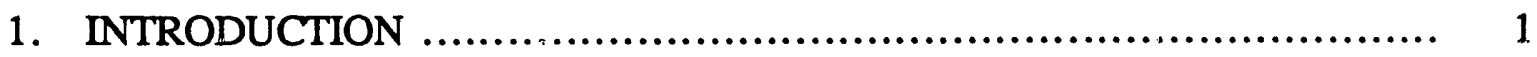

1.1 PROGRAM REQUIREMENTS AND OBJECTIVES ......................... 1

1.2 GENERAL SITE HYDROLOGY ................................... 1

$1.3 \mathrm{LLW}$ DISPOSAL AND TRU STORAGE FACILITIES ................. 2

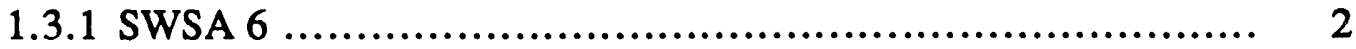

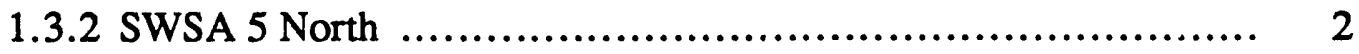

2. TUMULUS MONITORING ACTIVITIES ….............................. 3

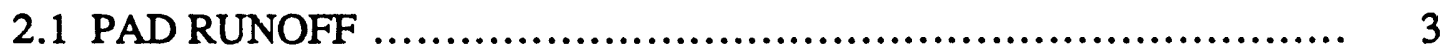

2.1.1 Methodology ................................................... 3

2.1.2 Tumulus I Results .......................................... 3

2.1.3 Tumulus II Results .......................................... 4

2.2 GROUNDWATER MONITORING …............................. 4

2.2.1 Methodology ................................................ 4

2.2.2 Radiological and Chemical Results ................................... 5

2.3 RECOMMENDATIONS ............................................. 5

3. OTHER ACTIVE SITES IN SWSA 6 ..................................... 6

3.1 LLW SILOS, AUGER HOLES, FISSILE WELLS, AND ASBESTOS SILOS ................................................................ 6

3.1.1 Methodology ............................................... 6

3.1.2 Results and Discussion ....................................... 6

3.2 HIILCUT DISPOSAL TEST FACILITY ............................. 7

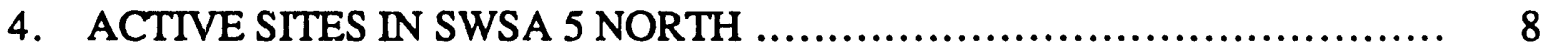

4.1 GROUNDWATER MONITORING ................................ 8

4.1.1 Methodology ................................................ 8

4.1.2 Results and Discussion ...................................... 8 


\section{CONTENTS (continued)}

Page

4.2 STREAM AND SEEP MONTTORING ............................. 9

4.2.1 Methodology .................................................. 9

4.2.2 Results and Discussion ...................................... 9

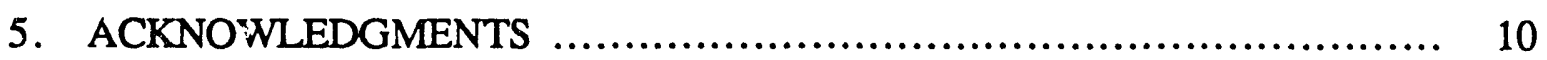

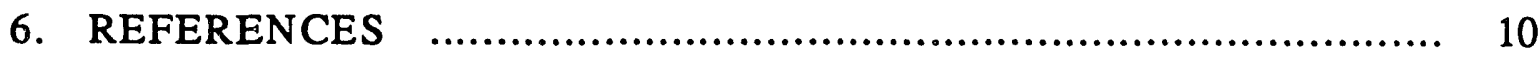

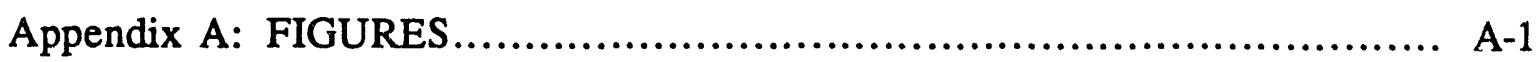

Appendix B: TABLES...................................................... B-1

Appendix C: TUMULUS AREA WELL LOGS .............................. C-1 


\section{LIST OF FIGURES}

Figure

Page

A.1 Low-level radioactive waste sites in SWSA 6 .............................. A-2

A.2 Transuranic waste storage sites in SWSA 5 North ...................... A-3

A.3 Tumulus area in SWSA 6 ........................................... A-4

A.4 Values for $\mathrm{pH}$ of Tumulus I pad runoff (March through

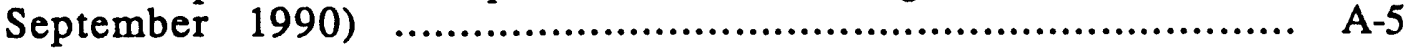

A.5 Specific conductance of Tumulus I pad runoff (March through

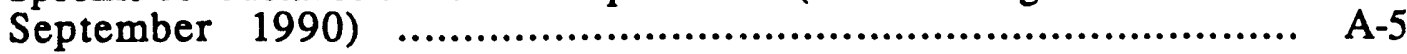

A.6 Gross alpha concentrations in Tumulus I pad runoff (March through September 1990) ............................................................... A-6

A.7 Gross beta and $40 \mathrm{~K}$ concentrations in Tumulus I pad runoff (March through

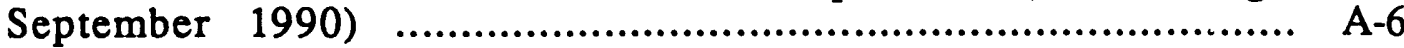

A.8 Cobalt-60 concentrations in Tumulus I pad runoff (March through September 1990)

A.9 Cesium-137 concentrations in Tumulus I pad runoff (March through September 1990)

A.10 Total organic carbon (TOC) in Tumulus I pad runoff (March through September 1990)

A.11 Water table contours around tumulus area in SWSA 6 (31 August 1990).... A-9

A.12 Tritium concentrations in tumulus monitoring wells 1036 and 1039 ........ A-10

A.13 Locations of intratrench wells in SWSA 6 low-activity silos area north ...... A-11

A.14 Locations of intratrench wells in SWSA 6 high-activity silos area .......... A-12

A.15 Locations of intratrench wells in SWSA 6 low-activity silos area south ...... A-13

A.16 Locations of new wells near SWSA 6 high-activity auger holes .............. A-14

A.17 SWSA 5 North groundwater elevations in wells 513, 514, 523, and 524 ... A-15

A.18 SWSA 5 North groundwater elevations in wells 516, 517, 518, and $521 \ldots$ A-15

A.19 SWSA 5 North groundwater elevations in wells 519, 520, 522, and 525 ... A-16

A.20 Cross section of area between wells 516 and 518 in SWSA 5 North with groundwater elevations for September 1990 


\section{LIST OF TABLES}

Table

B.1 Field parameters, radionuclide concentrations, and TOC values for Tumulus I (April through July 1990)

B.2 Field parameters, radionuclide concentrations, and TOC values for Tumulus I (August through September 1990) and Tumulus II (May through September 1990)

B.3 Field parameters and radionuclide concentrations for tumulus area groundwater wells

B.4 Cation, anion, and TOC concentrations in tumulus area groundwater wells

B.5 Radionuclide concentrations in intratrench wells in SWSA 6 (January through August 1990)

B.6 Radionuclide concentrations in intratrench wells in SWSA 6 (September 1990)

B.7 Results from ${ }^{90} \mathrm{Sr}$ and ${ }^{3} \mathrm{H}$ analyses of samples from intratrench wells in SWSA 6

B.8 Radionuclide concentrations in sample splits from SWSA 5 North well 516 analyzed by different laboratories

B.9 Radionuclide concentrations in water samples from quarterly sampling of streams and seeps near SWSA 5 North

B.10 Radionuclide concentrations in sediment samples from quarterly sampling of streams and seeps near SWSA 5 North 


\section{ABBREVIATIONS AND ACRONYMS}

ACD Analytical Chemistry Division

ASEMP Active Sites Environmental Monitoring Program

CS Composite sample

DOE U.S. Department of Energy

ESD Environmental Sciences Division

GCD Grearer Confinement Disposal

HASRD Health and Safety Research Division

HDTF Hillcut Disposal Test Facility

IT Intratrench

IWMF Interim Waste Management Facility

LLW Low-level waste

PWT Perched water table

ORNL Oak Ridge National Laboratory

SWSA Solid Waste Storage Area

TMOI Tumulus I

TMOII Tumulus II

TOC Total organic carbon

TRU Transuranic

UND Underpad drain

WOC White Oak Creek 


\section{EXECUTIVE SUMMARY}

This report summarizes the second half of FY 1990 activities of the Active Sites Environmental Monitoring Program (ASEMP) established by Solid Waste Operations and conducted by the Environmental Sciences Division in accordance with Chaps. II and III of DOE Order 5820.2A. The ASEMP provides for early detection of contaminant release and for performance monitoring of active low-level waste (LLW) disposal sites and transuranic waste storage sites at Oak Ridge National Laboratory.

Surface runoff, groundwater, and soil monitoring data continue to demonstrate that radioactive materials disposed of on the Tumulus I pad are not leaching out into the environment. The $\mathrm{pH}$ of the runoff from the Tumulus I pad continues to exceed 9.0. Recent measurements show that the $\mathrm{pH}$ of the runoff from the newly constructed Tumulusi II pad is below 8.0.

The tritium concentration is $\sim 6000 \mathrm{~Bq} / \mathrm{L}$ in Tumulus I well 1036 and $\sim 500 \mathrm{~Bq} / \mathrm{L}$ in Tumulus I well 1039. The likely source of the tritium has been identified as along-strike transport from another area of Solid Waste Storage Area (SWSA) 6. Solid Waste Operations personnel have installed a corrective action that should reduce tritium levels within a year.

Approximately 40 more wells were installed adjacent to silos, auger holes, and fissile wells. Samples from 2 intratrench wells adjacent to active LLW silos have shown gross beta concentrations above the $5 \mathrm{~Bq} / \mathrm{L}$ action level.

Groundwater samples and groundwater elevation measurements suggest that transuranic elements are being leached from casks buried in trenches in the southwest corner of SWSA 5 North. An action plan to further investigate the extent of contamination has been prepared. Gross alpha concentrations above background have been detected at one location in the stream south of SWSA 5 North. Tritium has been detected in one well on the northern edge of SWSA 5 North and in stream and seep samples around SWSA 5 North. 


\section{INTRODUCTION}

\subsection{PROGRAM REQUIREMENTS AND OBJECTIVES}

Chapter III of U.S. Department of Energy (DOE) Order 5820.2A (DOE 1988) sets forth requirements for environmental monitoring of active low-level waste (LLW) disposal sites. Active sites are defined as those LLW facilities that were in use on or after the date of the order (September 1988). The transuranic (TRU) waste storage areas in Solid Waste Storage Area (SWSA) 5 North are covered by Chap. II of the order. In both chapters, monitoring is required to provide for early warning of leaks before thos leaks pose a threat to human health or the environment. Chapter III also requires that monitoring be conducted to evaluate the short- and long-term performance of LLW disposal facilities. In accordance with this order, the Solid Waste Operations Department at Oak Ridge National Laboratory (ORNL) has established an Active Sites Environmental Monitoring Program (ASEMP) that is implemented by staff of the Environmental Sciences Division (ESD) at ORNL.

This report summarizes data from ASEMP monitoring activities for the final 6 months of FY 1990. A brief summary of the monitoring methodology for each site is presented also. Further details can be found in the ASEMP Program Plan (Ashwood et al. 1990a). Data are presented in summary form to support particular points. ASEMP activities from the first 6 months of FY 1990 are summarized in Wickliff et al. (1991) and Ashwood et al. (1990b).

\subsection{GENERAL SITE HYDROLOGY}

Moore $(1988,1989)$ suggests that most of the groundwater flow around ORNL occurs laterally in a storm flow zone from the surface to a depth of up to $2 \mathrm{~m}$. This zone typically has a hydraulic conductivity much greater than deeper zones and is active when infiltrating precipitation exceeds the soil moisture deficit (Moore 1988, 1989). Water in the storm flow zone moves rapidly to surface water drainages.

Radionuclide $\left({ }^{3} \mathrm{H},{ }^{90} \mathrm{Sr}\right.$, and $\left.{ }^{137} \mathrm{Cs}\right)$ transport in SWSAs 4 and 5 is enhanced during and inmediately following storms. The majority of contaminant transport from SWSA 5 to the Melton Branch watershed occurs along discrete pathways. Where these pathways intercept streams, the contaminated groundwater is discharged as seeps.

Although waste trenches are typically installed at least $0.6 \mathrm{~m}(2 \mathrm{ft})$ above the highest recorded water table (Boegly 1984), storm flow can introduce water into the trenches. Because the disturbed soil in waste trenches has a higher porosity and hydraulic conductivity than the surrounding media, groundwater infiltrates into the trenches faster than it can flow out again. Th is, standing water can remain in trenches for some time following storms. Solomon et al. (1988) summarized water level data collected from 1975 to 1988 from unlined waste trenches in SWSA 6. They estimated that $85 \%$ of the trenches had standing water during some part of that period. 


\subsection{LLW DISPOSAL AND TRU STORAGE FACILITIES}

\subsubsection{SWSA 6}

At ORNL, LLW has been disposed of in greater confinement disposal (GCD) facilities in SWSA 6 since 1986 (Davis et al. 1989). These facilities (Fig. A.1) consist of steel and ccncrete silos in excavated trenches, steel-lined auger holes and fissile wells, and tumulus-type facilities (Ashwood et al. 1990a).

Three types of GCD silo construction have been used in SWSA 6 (Davis et al. 1989). The oldest type consisted of concrete pipe segments with a poured concrete bottom. Wastes were placed in these pipes, and a concrete cap was poured in place. The second and third silo-construction techniques involve the use of concentric steel pipe sections of slightly different diameters. Concrete is pourec in the annular space between the pipe sections. These latter silo-types also have poured concrete bottoms and caps. The difference between the two types is that in the more recent silos grout is poured into the silos to fill the void spaces after the waste is emplaced. Both high-and low-activity LLW is disposed of in silos.

Auger holes and fissile wells consist of a steel pipe with a poured concrete base and a concrete plug cap. Auger holes may consist of a single pipe or a cluster of pipes having a concrete cap poured around all the pipes in the cluster. Auger holes are used for the highest-activity LLW.

Tumulus facilities consist of a concrete pad over a gravel drain layer. Concrete vaults containing grouted LLW are placed on the pad. The entire structure will eventually be covered with a multilayer engineered caf.

\subsubsection{SWSA 5 North}

TRU wastes are stored in three types of facilities in SWSA 5 North: concrete caves, auger holes, and trenches (Fig. A.2). Monitoring of the sumps in the caves is conducted by Solid Waste Operations personnel and is not covered by the ASEMP.

Auger holes are similar to those in SWSA 6. These holes are designied for always safe placement of the wastes. A concrete apron is poured around all of the auger holes.

Trenches were used in the earliest phases of operations at SWSA 5 North. Wastes placed into the 10 to 20 -ft-deep trenches were typically contained in concrete casks or plywood boxes (Stewart et al. 1989). 


\section{TUMULUS MONITORING ACTIVITIES}

\subsection{PAD RUNOFF}

\subsubsection{Methodology}

Pad surface runoff from either Tumulus I or Tumulus II is directed to a monitoring shed by the opening and closing of appropriate valves (Fig. A.3). Flow rate through a 1 -in. Parshall flume in the shed is monitored using a flow totalizer with an ultrasonic water level indicator.

Sampies of pad runoff are collected using a flow proportional composite sampler. The flow recorder sends a signal to the sampler to activate the collection of a $500 \mathrm{~mL}$ sample after every $500 \mathrm{~L}$ of flow from the pad. After each rainfall that produces sufficient runoff to trigger sample collection, the $\mathrm{pH}$ and specific conductance of the composite sample are measured and the sample is sent to ORNL's Analytical Chemistry Division (ACD) for gross alpha, gross beta, gamma scan, and total organic carbon (TOC) analyses.

Quarterly samples of the underpad drainage from both Tumulus I and II (Fig. A.3) are taken directly from the underpad drain lines inside the monitoring shed. The $\mathrm{pH}$ and specific conductance of these samples are measured, and they are sent to ACD for gross alpha, gross beta, gamma scan, and ${ }^{3} \mathrm{H}$ analyses. The perched water table (PWT) in the construction base d:ain underneath Tumulus I is also sampled quarterly for the same parameters as are the underpad drainages.

\subsubsection{Tumulus I Results}

Forty composite samples and two samples taken directly from the pad were analyzed during this 6-month reporting period. Loading of the pad was completed in late May 1990, and a temporary cover was installed over the pad at the end of June to minimize the flow from Tumulus I in preparation for the loading and monitoring of Tumulus II. Therefore, samples numbered TMOI- CS-284 through TMOI-CS-322 (Table B.1) were collected before the covcr was installed, and the remaining samples through TMOI-CS-360 were collected after the installation of the cover.

Comparison of the recorded pad runoff with the expected runoff based $c .7$ rainfall amount suggests that the cover is preventing approximately $99 \%$ of the rainfall tiom reaching the pad. However, there has been sufficient runoff from the covered pad to initiate sample collection by the composite sampier after most rainfall events.

Water also collects on the pad in the absence of rainfall during periods of high temperature and humidity as a result of condensation under the cover. During one extremely hot and humid 24-h period, approximately $8 \mathrm{~L}$ of water collected above the plugged surface drain lines (L.C. Williams, ORNL, personal communication, to C. M. Morrissey, ORNL, 1990).

Figures A.4 through A.10 present the runoff data in graphical form. The $\mathrm{pH}$ of the runoff increased somewhat after the installation of the cover and has exceeded 10.0 on several occasions (Fig. A.4). Specific conductance (Fig. A.5) and TOC (Fig. A.10) also increased significantly after the pad was covered. 
Gross alpha concentrations have remained at the minimum detectable level (Fig. A.6). However, every sample collected after the cover was installed exceeded the first action level for gross beta activity of 5.0 Bq/L (Fig. A.7). Elevated gross beta concentrations appear to be a result of $40 \mathrm{~K}$. Cobalt -60 concentrations remain at or near the detection limit (Fig. A.8), especially when counting errors are considered. Cesium-137 was reported in both the pad runoff and the perched water table samples collected during July and early August. Samples both before and after this period of time indicated no detectable levels of ${ }^{137} \mathrm{Cs}$ (Fig. A.9). This anomaly is probably attributable to sampling or analytical error because ${ }^{137} \mathrm{Cs}$ was also reported in two blank samples of deionized water taken during this same period.

Analytical results from samples of the perched water table (TMOI-PWT) are included in Tables B.1 and B.2. Radionuclide parameters are below any action levels except for the anomalous ${ }^{137} \mathrm{Cs}$ concentrations reported for the sample collected in July.

The underpad drain line was repaired early in 1990 and remained dry until June when water was noted in the underpad sump area. Since then, water has been present in this line and was sampled in July and found to be below any radionuclide action levels (TMOI-UND, Table B.1).

\subsubsection{Tumulus II Results}

Construction of Tumulus II is complete, but loading is not scheduled to begin until October 1990. Five preoperational samples of runoff from the Tumulus II pad were collected from either the outfall pipe leading to the adjacent creek or from a sampling port at the surface drain valves. The decrease in $\mathrm{pH}$ (Table B.2) for the TMOII-CS series samples is probably the result of an organic sealant that was applied to the pad on August 30 in an attempt to prevent hydrolysis of the concrete and the resulting high $\mathrm{pH}$ of pad runoff. Samples collected during July showed low levels of ${ }^{137} \mathrm{Cs}$ that are probably attributable to analytical error as discussed in the preceding section.

The underpad drain was sampled on two occasions (TMOII-UND, Table B.2). The June sample showed a slightly elevated level of ${ }^{3} \mathrm{H}$ that was not observed in the July sample. The June ${ }^{3} \mathrm{H}$ activity was still within the range of background values for SWSA 6.

\subsection{GROUNDWATER MONITORING}

\subsubsection{Methodology}

The tumulus pads are encircled by 12 shailow groundwater wells (Fig. A.3) that are continuously monitored for water level using pressure transducers and data logging equipment. The purpose of continuous monitoring of water levels is to estimate the general direction of groundwater flow in the area and to detect any impacts of tumulus operations on the shallow groundwater flow system in the area. Groundwater contours (Fig. A.11) indicate that groundwater generally flows to the south toward White Oak Lake and to the southwest toward a tributary that drains SWSA 6. Wells 1254 through 1259 were installed and developed during May and June of this reporting period. Appendix C contains the well logs and construction diagrams for 12 tumulus wells (including well 1035 that was destroyed during construction of Tumulus II but not including well 381 which existed prior 
to tumulus activities).

All wells, except for 381, are equipped with dedicated bladder pumps and are sampled quarterly for radiological and field parameters and annually for cations, anions, and TOC. In addition, a subset of the monitoring wells is sampled on an annual basis for volatile and semivolatile organics.

\subsubsection{Radiological and Chemical Results}

Gross alpha, gross beta, and gamma scans indicate no concentrations above action levels (Table B.3). Elevated ${ }^{3} \mathrm{H}$ concentrations in wells 1036 and 1039 have been observed and reported previously (Wickliff et al. 1991). Figure A.12 presents the history of $3 \mathrm{H}$ concentrations in these two wells since the beginning of the tumulus project. The source of this $3 \mathrm{H}$ is belie: ed to be the outfall of a French drain that drains the 49-trench area (see Davis et al. 1985) that is along strike with Tumulus I. Solid Waste Operations personnel have taken corrective action within the last year to extend this outfall to a surface drainage area so that the water from the outfall will not seep into the ground and travel to the tumulus area. Based on estimated travel times for groundwater in the area, it will take at least a year for ${ }^{3} \mathrm{H}$ concentrations in these wells to decline. Slightly elevated levels (but still near background) of ${ }^{3} \mathrm{H}$ have been measured in wells 1255 to 1258 , which are generally to the north of the Tumulus II pad.

The annual anion, cation, and TOC data (Table B.4) are within the range of values normally observed in the SWSA 6 area (Boegly 1984) and thus indicate no unusual groundwater chemistry in the area.

Annual sampling for volatile and semivolatile organics was performed on a subset of the Tumulus wells (Wells 1254, 1257, 1259, 1036, 1037, 1039, and 1041). No organics other than very low concentrations of some common laboratory and sampling contaminants were detected.

\subsection{RECOMMENDATIONS}

Based on the results to date we offer the following recommendations for future monitoring of the tumulus pads.

1. It is appropriate to keep the Tumulus I drain valves closed while monitoring runoff from Tumulus II and to periodically release the accumulated water from I imulus I as necessary. This will allow independent monitoring of the performance of the two facilities. It is especially important to track the elevated $\mathrm{pH}$, gross beta, and $40 \mathrm{~K}$ levels from Tumulus I because of their potential implications about the integrity of the concrete vaults and pad.

2. There is some question concerning the integrity of the buried surface drain lines from both pads and from the monitoring shed to the creek discharge. Several observations indicate that water is entering these lines from the outside, raising questions concerning what water is actually being sampled, an especially important matter at the monitoring shed outfall because it is a National Pollutant Discharge Elimination System sampling point. It is recommended that these lines be tested for leakage and corrective actions be taken if necessary. 
3. Continuous-reading $\mathrm{pH}$ probes should be installed at the discharge of the line to the creek and in tue monitoring shed to provide more quantitative information regarding changes with time and flow rate in the $\mathrm{pH}$ of runoff from the tumulus pads.

\section{OTHER ACTIVE SITES IN SWSA 6}

\subsection{LLW SILOS, AUGER HOLES, FISSILE WELLS, AND ASBESTOS SILOS}

\subsubsection{Methodology}

LLW silos in SWSA 6 are installed in groups of two to four within a single trenc's. Davis et al. (1989) have demonstrated that some of these silos leak. Therefore, to provide early contaminant detection within each trench, 2-in. drive-point monitoring wells were installed (generally one per trench) in trenches that previously were without monitoring wells. Thirty-one new intratrench (IT) wells, each with a 5-ft screened section, were driven 16 to $22 \mathrm{ft}$ into backfill around LLW silos (Figs. A.13-A.15). These intratrench wells provide a way to monitor groups of silos for containment failure, leaching of wastes, and contaminant transport.

Auger holes, fissile wells, and asbestos silos (not in trenches) are surrounded by a small volume of backfilled soil. This backfill material may also be subject to the same perched water table effect as the silo trenches. Therefore, eight wells were installed next to high-activity auger holes (Fig. A.16), two wells were installed near active fissile wells, and a well was installed next to both asbestos silos.

Weighted sample bottles left in IT wells collect water during intermittent times when a perched water table exists within the trench. Samples from these bottles are collected quarterly for gamma scans and for gross alpha and gross beta analyses. Most of the newly installed wells have not yet been equipped with sample bottles. However, 19 out of 43 wells had sufficient water within the drive point such that preliminary samples were collected using a small peristaltic pump.

Samples are prepared by acidifying the sample before it is filtered so that any contamination present is detected, whether it is part of the dissolved load or associated with suspended sediment in the well. Samples are first counted for gamma emitting radionuclides and then analyzed for gross alpha and gross beta activities.

\subsubsection{Results and Discussion}

Samples collected prior to September were analyzed by ESD. Gamma scans indicated that ${ }^{137} \mathrm{Cs}$ and ${ }^{60} \mathrm{Co}$ levels were close to, or below, detection limits. ESD gross alpha and gross beta analyses were suspected to be understated, and a few archived IT well samples were submitted to ACD as a check. Results (Table B.5) indicated that gross alpha and gross beta values determined by ESD were indeed understated. Comparison of gross beta results indicated that ESD gross beta values were 2 to 5 times lower than values from $A C D$. The understated values are suspected to be partially a result of attenuation of activity from too much residue on the planchette (i.e. the amount of residue was above self-absorption calibration corrections). All samples are now submitted to ACD for gross 
alpha and gross beta analyses.

$\mathrm{ACl}$-measured gross alpha values were still below the action level of $1 \mathrm{~Bq} / \mathrm{L}$, except for IT well 36. Gross beta results from samples submitted to ACD indicate two wells had gross beta concentrations that exceeded the action level of $5 \mathrm{~Bq} / \mathrm{L}$ (Table B.6). Water from IT well 13 collected on 20 September 1990 exceeded the action level by nearly a factor of two. Although ${ }^{90} \mathrm{Sr}$ analysis was not performed on this sample, previous samples from IT well 13 suggest that the gross beta concentration is not a result of ${ }^{90} \mathrm{Sr}$ (Table B.7). The 20 September 1990 sample was not counted long enough for a ${ }^{40} \mathrm{~K}$ determination. Future samples from IT well 13 will be submitted for longer count times to determine whether ${ }^{40} \mathrm{~K}$ may account for the gross beta concentrations.

The second well with gross beta concentrations above the action level was IT well 19. Concentrations of 50 to $60 \mathrm{~Bq} / \mathrm{L}$ were found during the last two quarterly samplings (Tables B.5 and B.6). Count times were not adequate to detect $40 \mathrm{~K}$. Samples from IT well 19 have not been analyzed for ${ }^{90} \mathrm{Sr}$. It is possible that one or more of the silos within the trench (Fig. A.13) have containment failure, allowing leaching and transport of contaminants-although, contamination could also be coming from a source outside the trench. Silos within this trench were put in place using the oldest construction technique (concrete drainage pipes), and the silos were not grouted. Only one of the 4 silos has a monitoring well. Water was never found in this well during monthly monitoring from January 1987 to February 1989 (Davis et al. 1989). During the first quarter of FY 1991, the monitoring well will be checked. If water is present, a sample will be collected. Samples from IT well 19 will be analyzed for ${ }^{40} \mathrm{~K}$ and ${ }^{90} \mathrm{Sr}$. Plans for further investigation of the contamination will be developed after this data is received and reviewed.

\subsection{HILLCUT DISPOSAL TEST FACILITY}

Runoff from the pad and from the underpad gravel drain is designed to collect in two above-grade tanks at the Hillcut Disposal Test Facility (HDTF). There was no runoff from the underpad gravel drain during the period April 1990 through September 1990. Volume measurements of pad runoff were made weekly and remained minimal during the period; thus, only one sample was collected from the tank for analyses. Results received from ACD showed gross alpha, gross beta, and gamma emitting radionuclides were at background concentrations.

The two wells at HDTF were monitored weekly during the period. The well in the gravel layer remained dry. Water levels in the well on the pad indicate that a small amount of standing water (depth $=<0.5 \mathrm{in}$ ) remains on the pad even during dry periods.

Installation of four groundwater wells around the facility has been delayed until approval of National Environmental Policy Act documentation is received from DOE. The wells will be used to define the hydrogeology of the area and to demonstrate that no contamination is leaving the site via groundwater.

A draft contingency plan has been prepared for the HDTF. The plan establishes action levels for monitoring of HDTF and operational responses if action levels are exceeded. 


\section{ACTIVE SITES IN SWSA 5 NORTH}

\subsection{GROUNDWATER MONITORING}

\subsubsection{Methodology}

Manual water level measurements are taken monthly, and water samples are collected quarterly from 12 wells located in and around SWSA 5 North (Fig. A.2). Most wells are purged prior to sample collection. Field parameters (temperature, specific conductance, and $\mathrm{pH}$ ) are measured during well purging and sampling. Samples are analyzed for gross alpha and gross beta concentrations and gamma emitting isotopes. Prior to August 1990 the method for groundwater collection in SWSA 5 North was to acidify the sample before it was filtered so that any contamination present would be detected, whether it was part of the dissolved load or associated with sediment that was suspended during sampling. However, to provide for better comparisons among wells and between sampling periods, the sampling procedure has been changed so that filtration of the sample occurs before acidification.

\subsubsection{Results and Discussion}

Monthly water level measurements taken through September 1990 indicate that September was the driest month during the monitoring period (Figs. A.17-A.19). Water levels in well 516 exhibited the greatest variability with groundwater $<2 \mathrm{ft}$ below ground surface in March, dropping to almost $13 \mathrm{ft}$ below in September.

Previous data suggested that, luring wetter periods, trenches in SWSA 5 North are in contact with the water table (Wickliff et al. 1991: Fig. 12). Recent data suggest that at least one trench may still be in contact with the water table even during relatively dry periods (Fig. A.20).

Results from the first two quarterly samplings of wells are found in Wickliff et al. (1991). During the period April 1990 through September 1990, the third and fourth quarterly samplings of wells were completed. Water from well 522 continues to have unusually high $\mathrm{pH}$. This is still thought to be a result of grout contamination during installation of the well and will require removal of several well volumes to obtain true groundwater pH values. Well 522 is not purged during quarterly sampling because the pump used currently is not able to lift water from the depth of well 522 .

Results from gamma scans indicated that ${ }^{137} \mathrm{Cs}$ and ${ }^{60} \mathrm{Co}$ levels were close to, or below, detection limits. With the exception of well 516, samples had gross alpha and gross beta concentrations that were below the action levels of 1 and $5 \mathrm{~Bq} / \mathrm{L}$, respectively. Well 516 continues to have elevated gross alpha (primarily $244 \mathrm{Cm}$ ) concentrations. The source of this contamination appears to be the trenches immediately northeast of the well (Fig. A.2). We have proposed a course of action for further investigation to characterize the extent of contamination.

In July 1990, a portion of the sample from well 516 was submitted to ACD for alpha spectroscopy and gross alpha analysis. As an additional check, another portion of the sample was submitted to the analytical chemistry laboratory at $\mathrm{Y}-12$ for gross alpha, gross beta, ${ }^{244} \mathrm{Cm}$, and ${ }^{241} \mathrm{Am}$ analyses (Table B.8). Gross alpha and gross beta results of the 
same sample analyzed by ESD had been understated. Samples collected since July 1990 have been submitted to ACD for analyses.

Split samples from well 516 were collected in August 1990 following the old methodology (acidification prior to filtration) and the new methodology (filtration prior to acidification). Gross alpha results indicate that approximately 70 to $90 \%$ of the alpha activity is associated with the dissolved phase rather than with sediment resuspended during sampling (Table B.8).

Results of split samples from well 516 collected in August 1990 and submitted for metals and organics analyses indicate that currently there are no organic or metal contamination problems associated with the alpha contamination.

Additional aliquots of groundwater samples collected in March 1990 were submitted for ${ }^{3} \mathrm{H}$ analyses. Well 524 just north of SWSA 5 North was the only well that had an elevated ${ }^{3} \mathrm{H}$ concentration $(300 \mathrm{~Bq} / \mathrm{L})$. Samples from a small stream (North Tributary) adjacent to well 524 (Fig. A.2) did not have elevated ${ }^{3} \mathrm{H}$. Gamma and gross alpha concentrations in quarterly samples from well 524 have always been below detection, and gross beta concentrations have always been $<1 \mathrm{~Bq} / \mathrm{L}$. The elevated ${ }^{3} \mathrm{H}$ level is below the National Primary Drinking Water Standard of $740 \mathrm{~Bq} / \mathrm{L}(20,000 \mathrm{pCi} / \mathrm{L})$. However, elevated levels suggest that ${ }^{3} \mathrm{H}$ is being transported in groundwater and may be an indicator of leaching of contaminants from buried or stored wastes.

\subsection{STREAM AND SEEP MONITORING}

\subsubsection{Methodology}

Water samples from North Tributary, the stream just north of SWSA 5 North, and South Tributary, the stream just to the south (Fig. A.2), are collected quarterly and analyzed for gross alpha, gross beta, and ${ }^{3} \mathrm{H}$ concentrations and gamma emitting isotopes. Sediment samples are also collected and analyzed quarterly for gross alpha and gross beta concentrations, gamma emitting isotopes, and heavy metals. Two seeps were also sampled.

\subsubsection{Results and Discussion}

Results of ${ }^{3} \mathrm{H}$ analyses for stream and seep samples collected in March 1990 are given in Table B.9. The stream samples to the south and seep samples to the west of SWSA 5 North (Fig. A.2) had elevated ${ }^{3} \mathrm{H}$ concentrations. As with the ${ }^{3} \mathrm{H}$ in well 524 , these elevated concentrations suggest that ${ }^{3} \mathrm{H}$ is being transported in groundwater and may indicate that leaching of buried or stored wastes is occurring. The seeps have been dry for the last few months, so additional samples have not been collected.

To investigate the gross alpha concentration found in the March 1990 sample from stream location 5NS 02 (Table B.9 and Wickliff et al. 1991), four stream water samples were collected in June from small pools upstream from 5 NS 02 . A sample was not collected at 5 NS 02 because the stream bed at the location was dry. Gross alpha concentrations in the samples were below detection. This stream reach will be resampled during wetter conditions when a sample can also be collected from site $5 \mathrm{NSO2}$, where 
gross alpha activity was found initially.

Quarterly stream monitoring was limited because water and new sediment were lacking in the South Tributary. Cesium-137, ${ }^{60} \mathrm{Co}$, gross alpha, and gross beta concentrations in stream samples collected during the quarterly samplings were close to background levels (Tables B.9 and B.10).

\section{ACKNOWLEDGMENTS}

We want to thank Della Marshall, Dan Marsh, Scott Gregory, Lauren Larsen, and Jeff Wade for valuable assistance in sampling and analysis of the data. John Van Cleve, Red Williams, and Harold Adair provided valuable information on activities in the SWSAs.

\section{REFERENCES}

Ashwood, T. L., D. S. Wickliff, and C. M. Morrissey. 1990a. Active sites environmental monitoring program: Program plan. ORNL/M-1197. Oak Ridge National Laboratory.

Ashwood, T. L., D. S. Wickliff, C. M. Morrissey, and H. L. Adair. 1990b. Active sites monitoring at Oak Ridge National Laboratory. pp. 397-399. In Proceedings of SPECTRUM 90 Nuclear and Hazardous Waste Management International Topical Meeting, September 30-October 4, 1990, Knoxville, Tennessee. American Nuclear Society, La Grange Park, Ill.

Boegly, W. J. Jr. 1984. Site characterization data for solid waste storage area 6. ORNL/TM-9442. Oak Ridge National Laboratory.

Davis, E. C., R. G. Stansfield, L. A. Melroy, and D. D. Huff. 1985. Water diversion at low-level waste disposal sites. J. Environ. Eng. 111(5):714-729.

Davis, E. C., C. W. Francis, and R. J. Luxmoore. 1989. An evaluation of water leakage into concrete low-level radioactive waste disposal silos at ORNL's Solid Waste Storage Area Six. ORNL/TM-11164. Oak Ridge National Laboratory.

Moore, G. K. 1988. Concepts of groundwater occurrence and flow near Oak Ridge National Laboratory, Tennessee. ORNL/TM-10969. Oak Ridge National Laboratory.

Moore, G. K. 1989. Groundwater parameters and flow systems near Oak Ridge National Laboratory. ORNL/TM-11360. Oak Ridge National Laboratory.

Solomon, D. K., R. C. Haese, T. V. Dinsmore, and A. D. Kelmers. 1988. Sampling and analysis of SWSA 6 trench leachates and groundwaters. ORNL/TM-10813. Oak Ridge National Laboratory.

Stewart, R. C., L. S. Dickerson, S. F. Joost, and D. C. Osucha. 1989. Remote-handled transuranic solid waste characterization study: Oak Ridge National Laboratory. ORNL/TM-11050. Oak Ridge National Laboratory.

U. S. Department of Energy (DOE). 1988. Radioactive Waste Management. DOE Order 5820.2A, 9/26/88. Washington, D.C.

Wickliff, D. S., C. M. Morrissey, and T. L. Ashwood. 1991. Active sites environmental monitoring program: mid-FY 1990 summary report. ORNL/M-1179 Oak Ridge National Laboratory. 
Appendix A:

FIGURES

A-1 


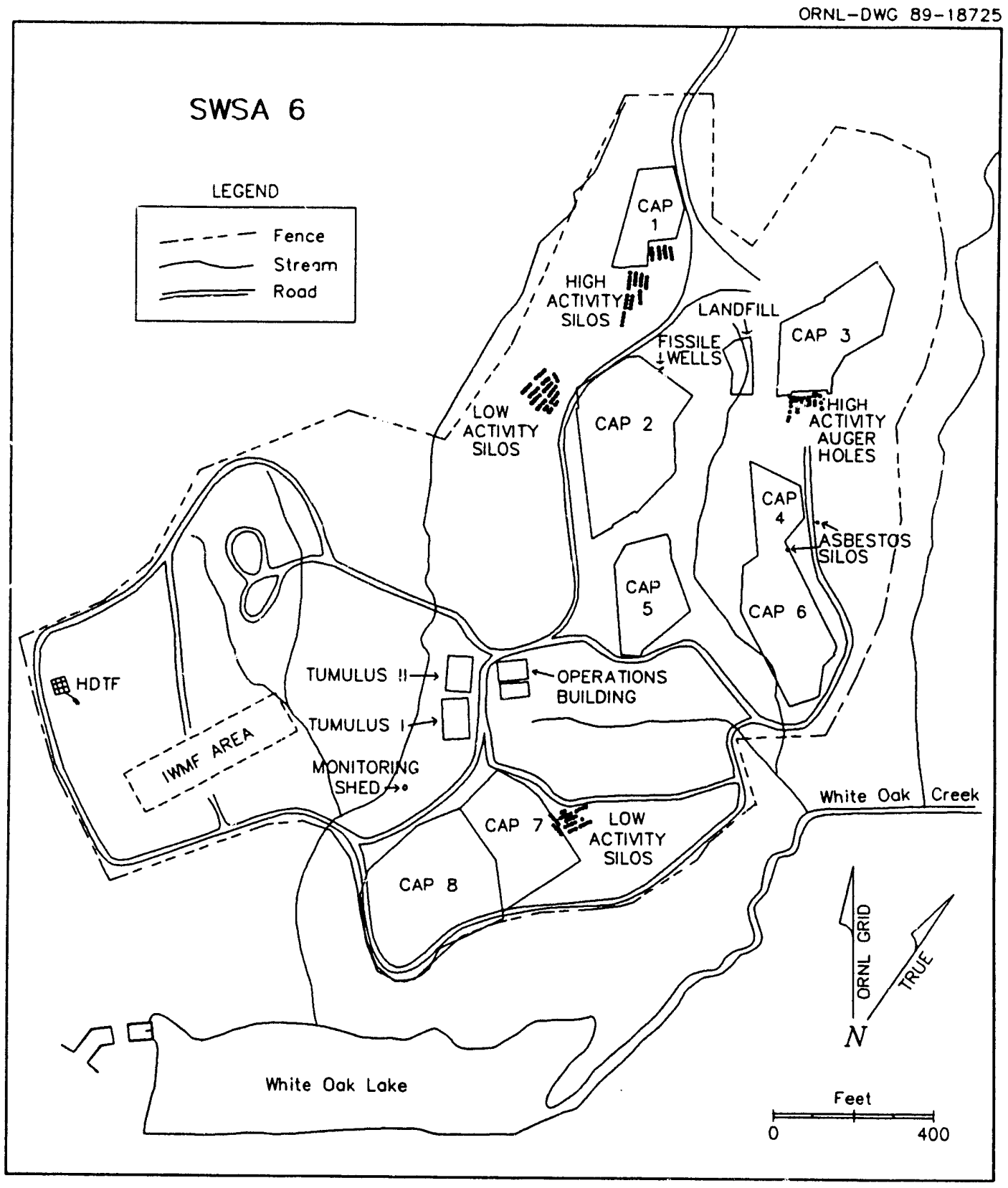

Fig. A.1. Low-level radioactive waste sites in SWSA 6. 


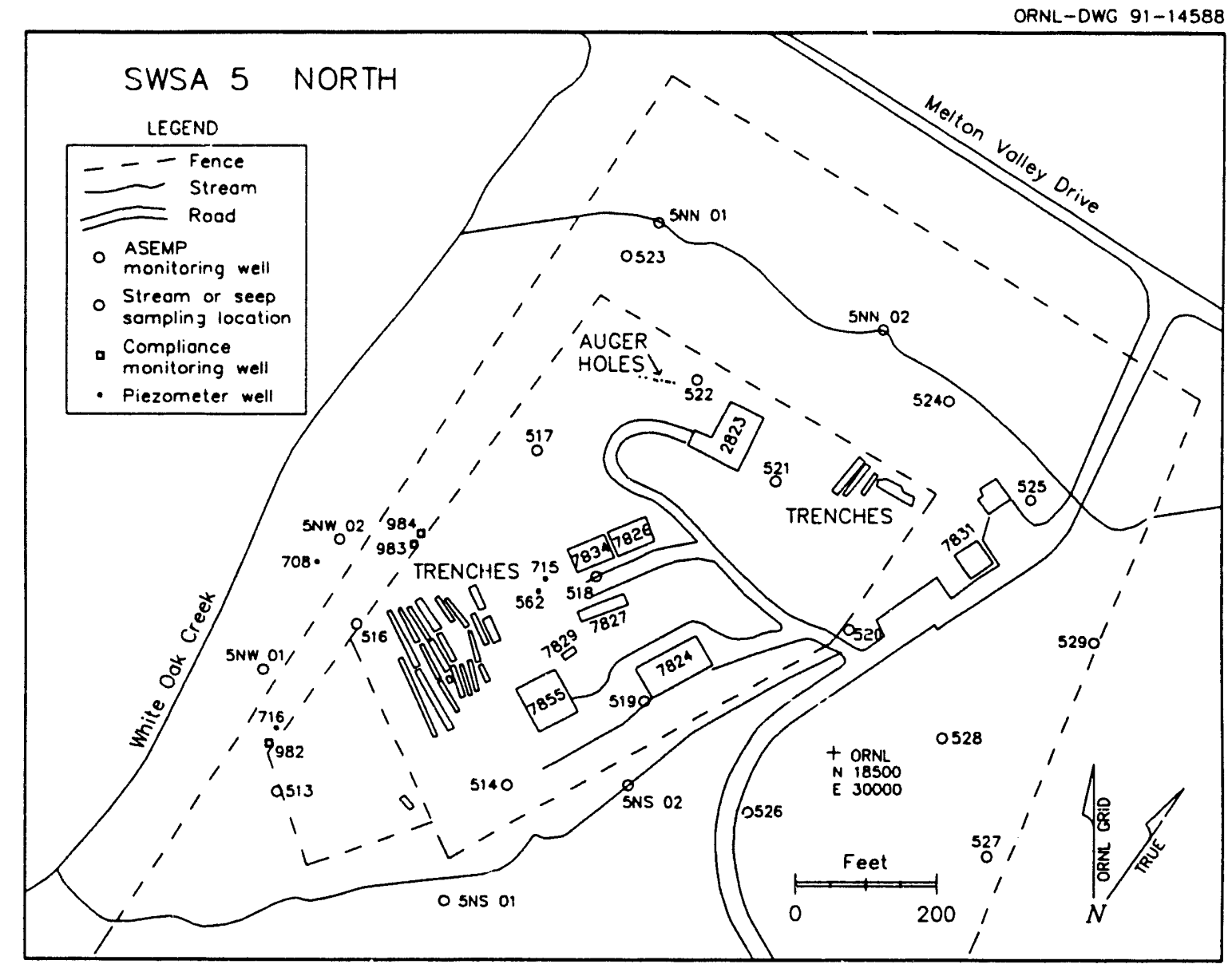

Fig. A.2. Transuranic waste storage sites in SWSA 5 North. 


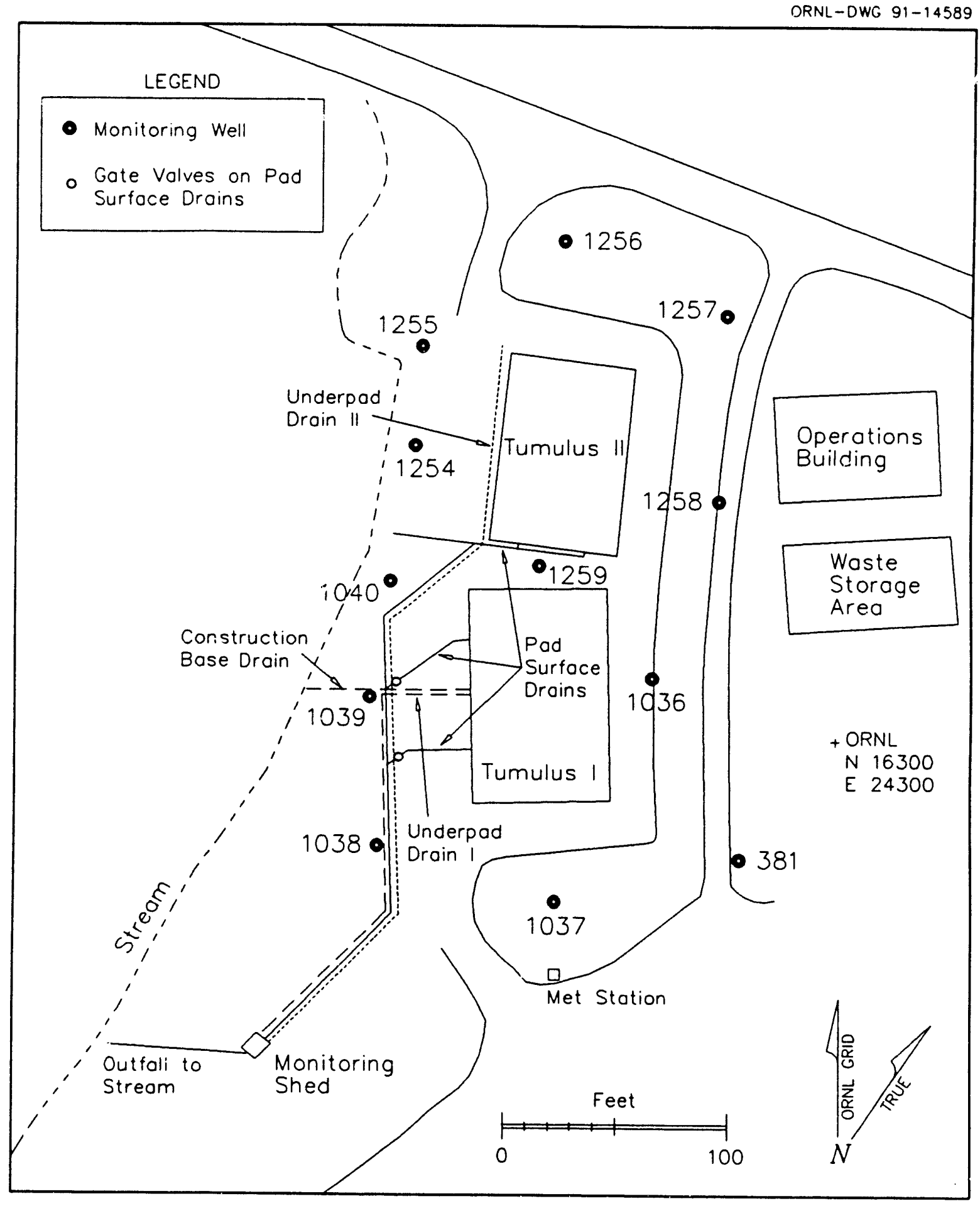

Fig. A.3. Tumulus area in SWSA 6. 


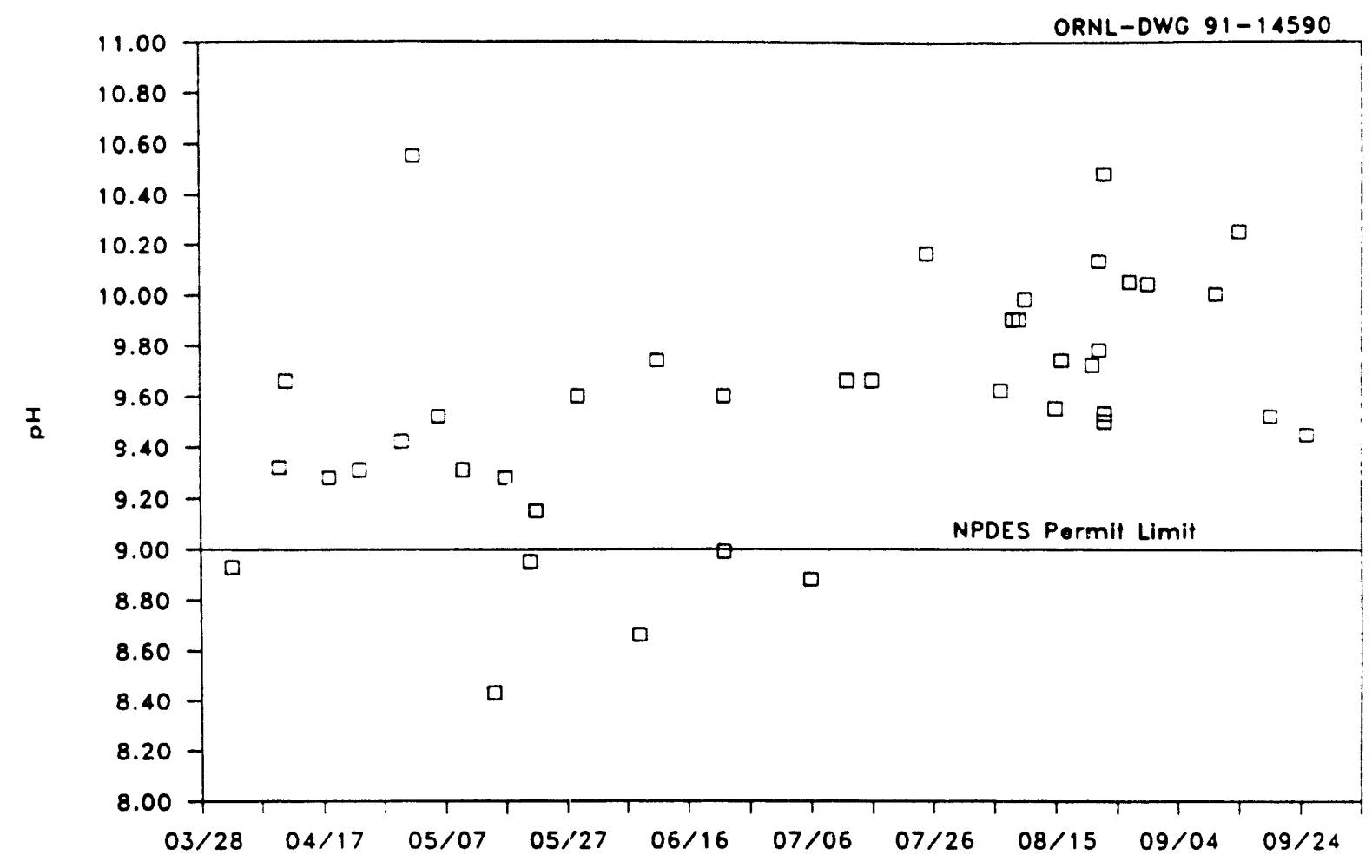

Fig. A.4. Values for pH of Tumulus I pad runoff (March through September 1990).

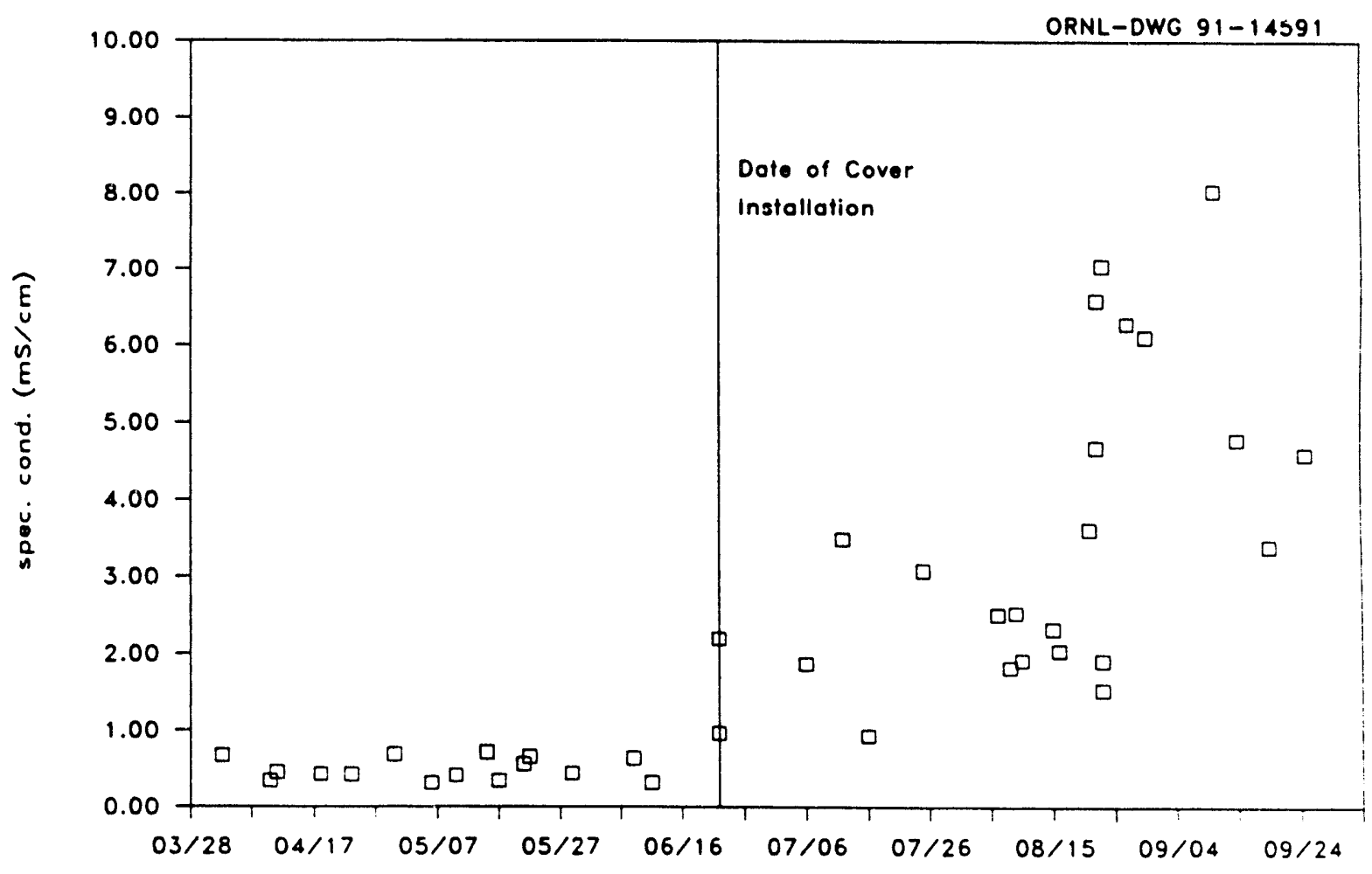

Fig. A.5. Specific conductance of Tumulus I pad runoff (March through September 1990). 


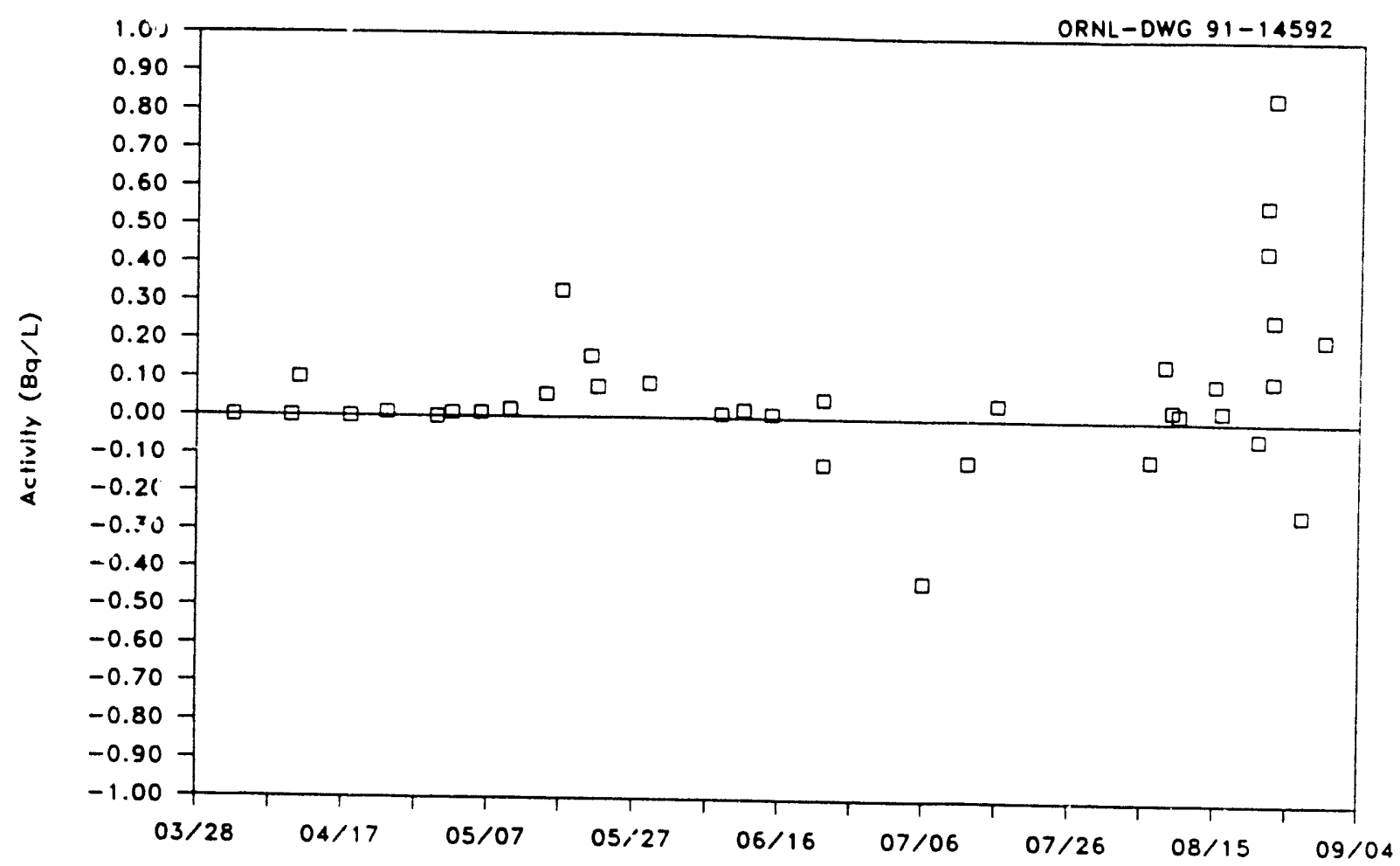

Fig. A.6. Gross alpha concentrations in Tumulus I pad runoff (March through September 1990).

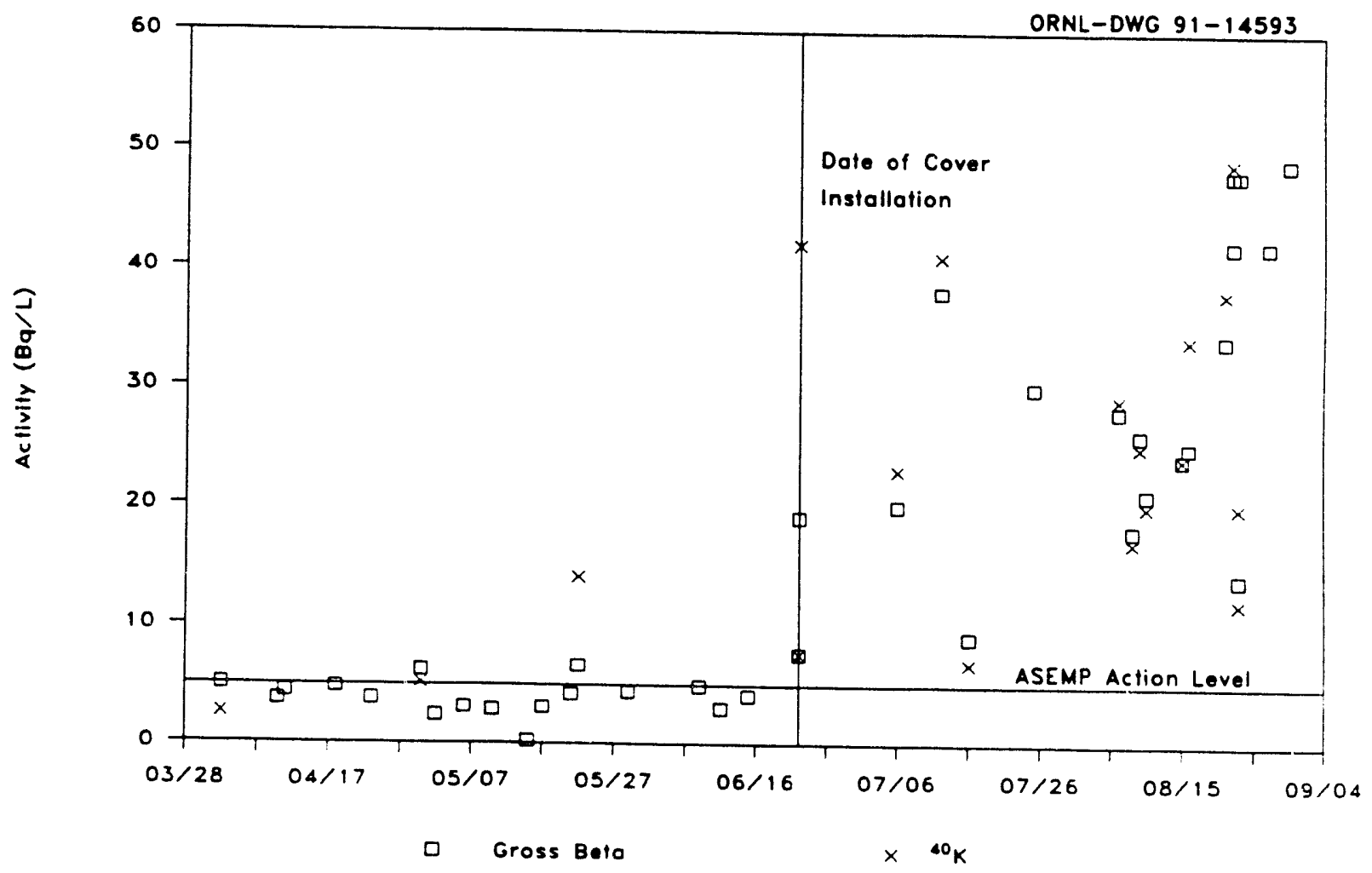

Fig. A.7. Gross beta and ${ }^{40} \mathrm{~K}$ concentrations in Tumulus I pad runoff (March through September 1990). 


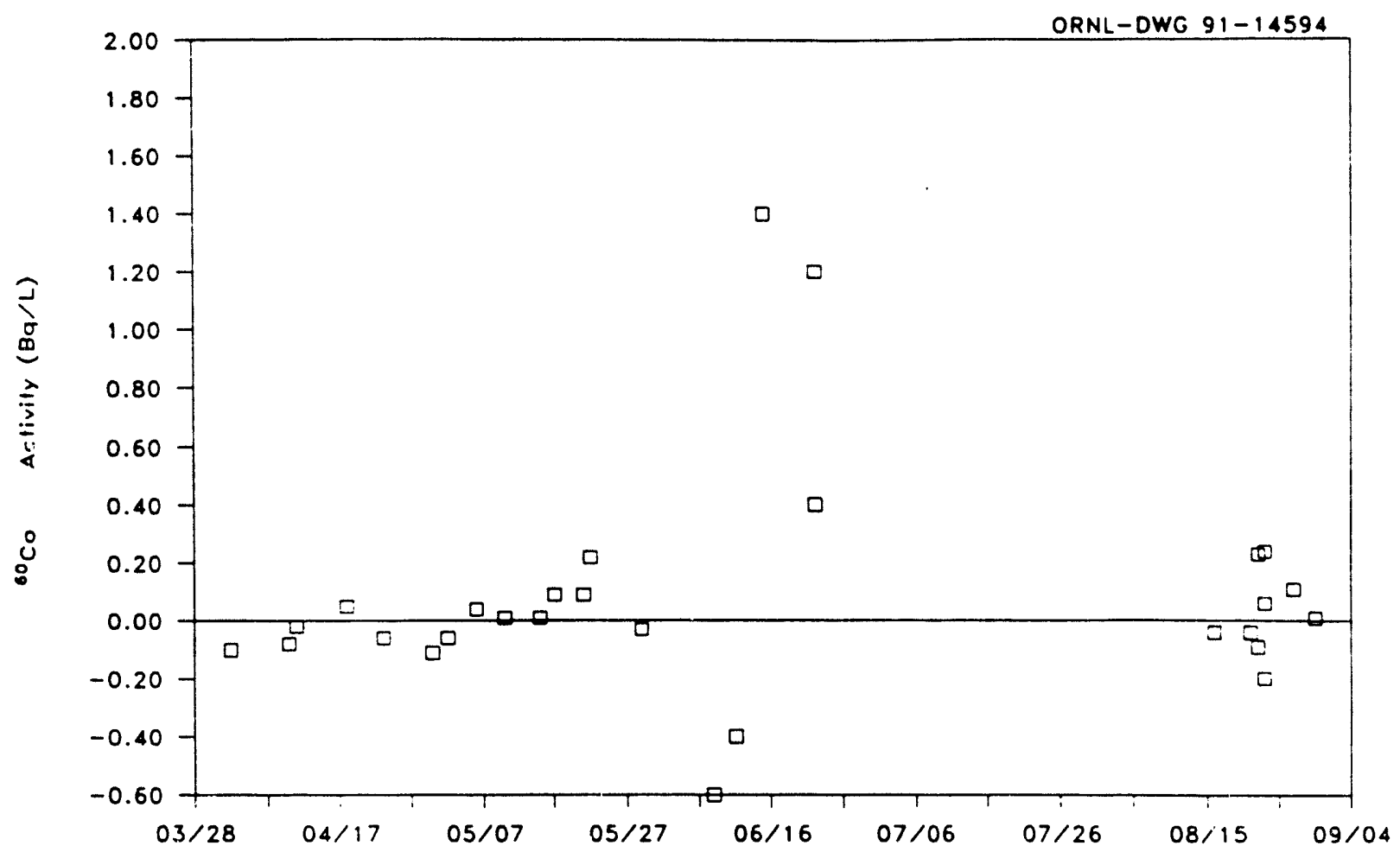

Fig. A.8. Cobalt-60 concentrations in Tumulus I pad runoff (March through September 1990).

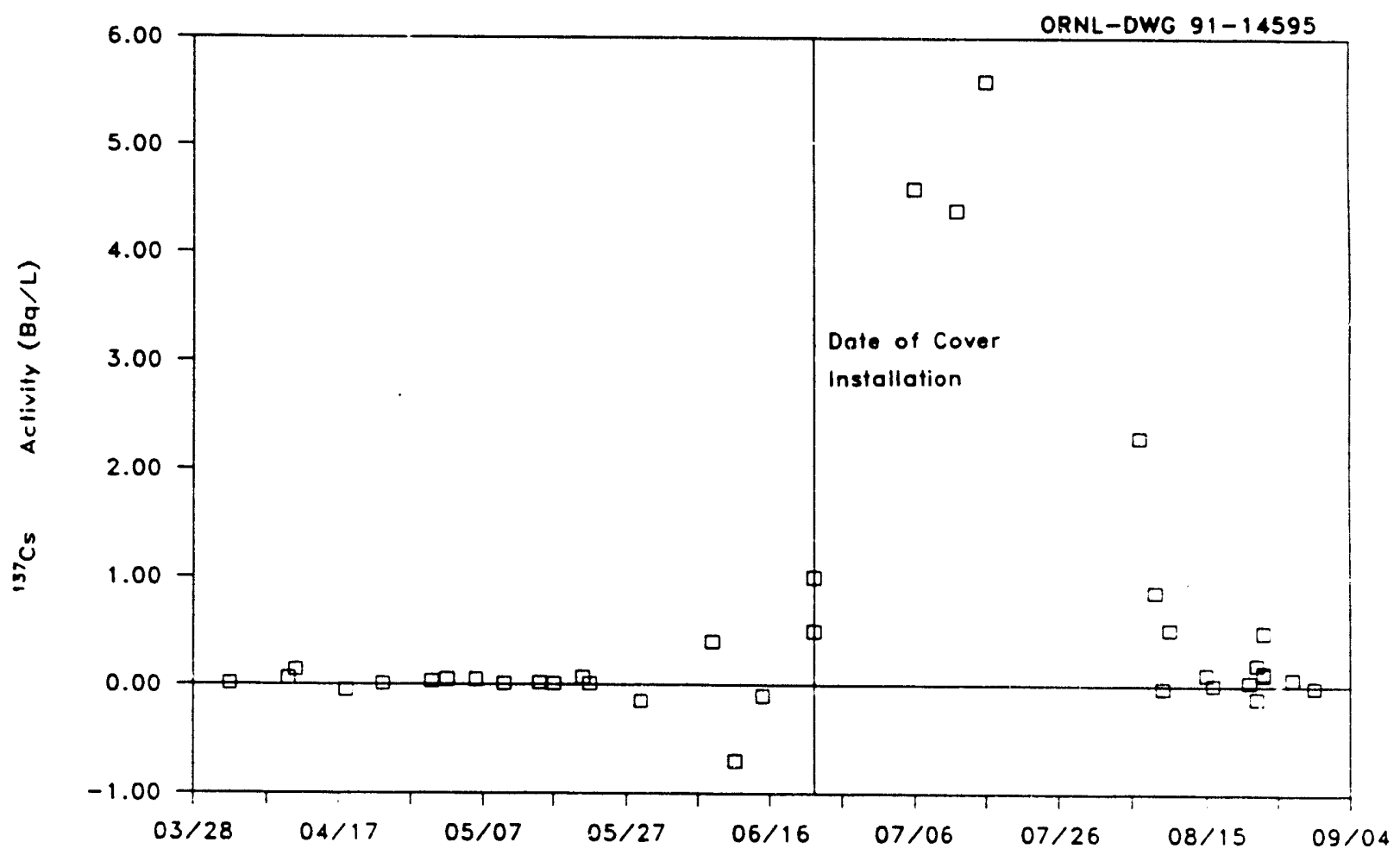

Fig. A.9. Cesium-137 concentrations in Tumulus I pad runoff (March through September 1990). 


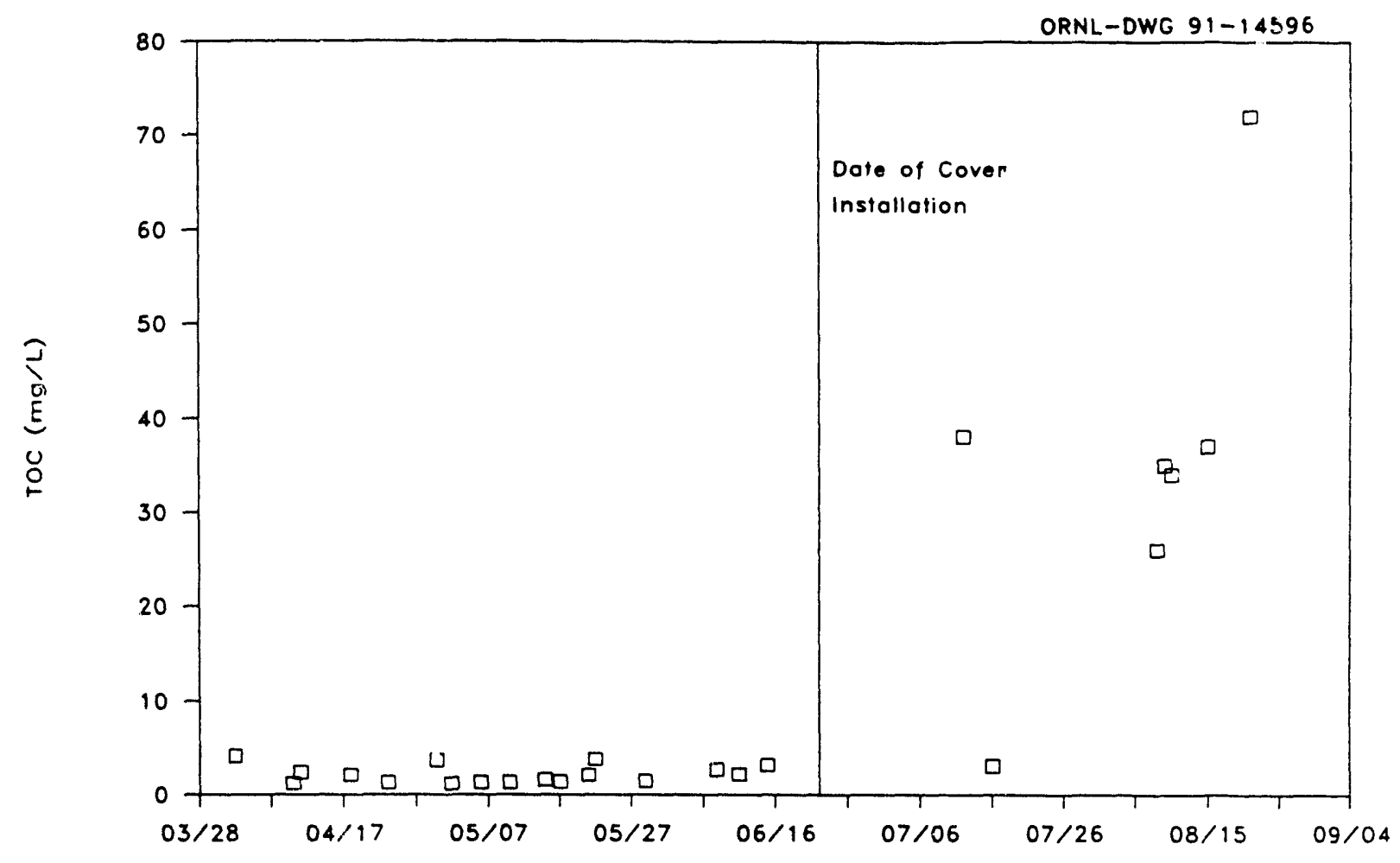

Fig. A.10. Total organic carbon (TOC) in Tumulus I pad runoff (March through September 1990). 


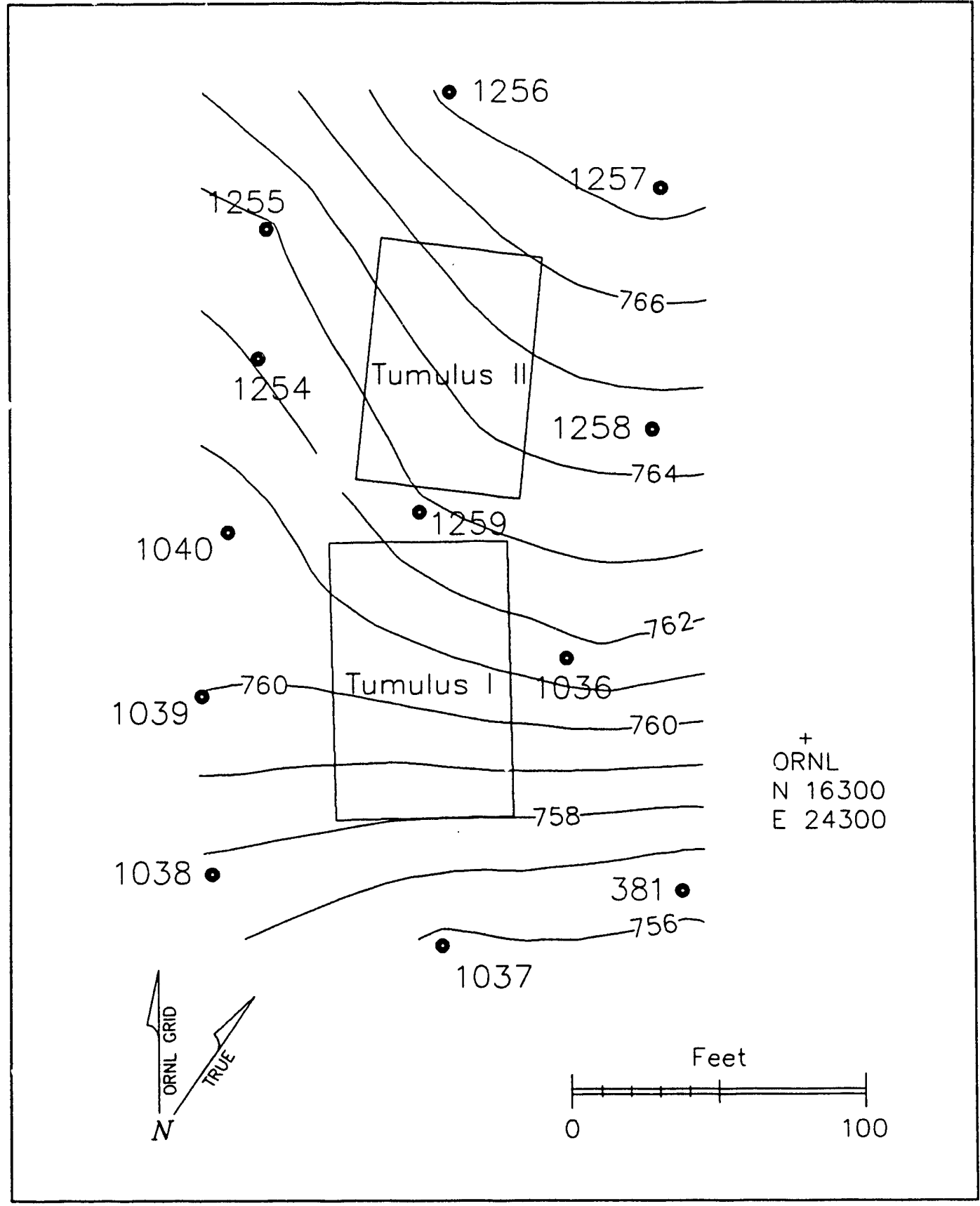

Fig. A.11. Water table contours around the tumulus area in SWSA 6 (31 August 1990). 


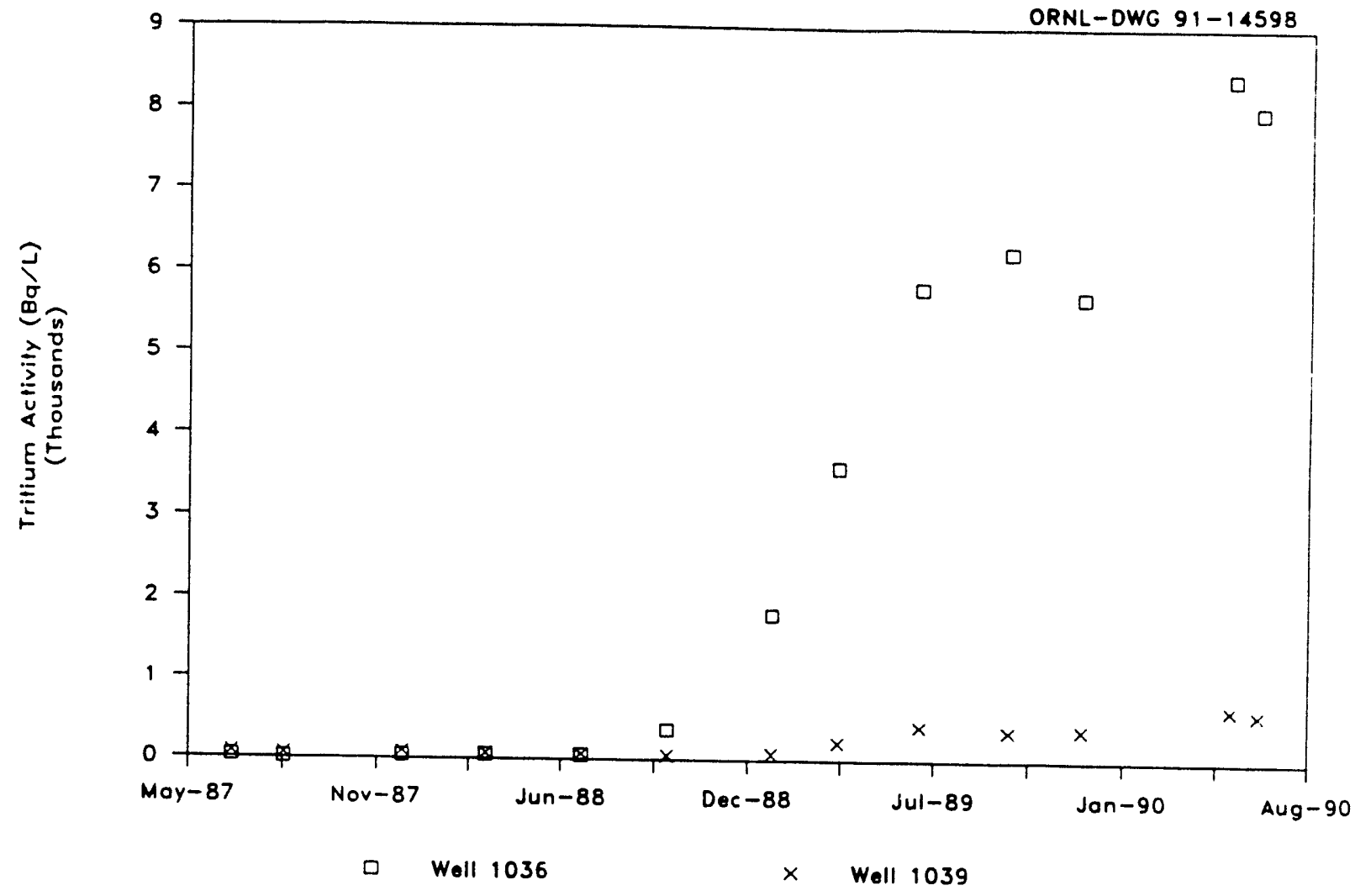

Fig. A.12. Tritium concentrations in tumulus groundwater wells 1036 and 1039 . 


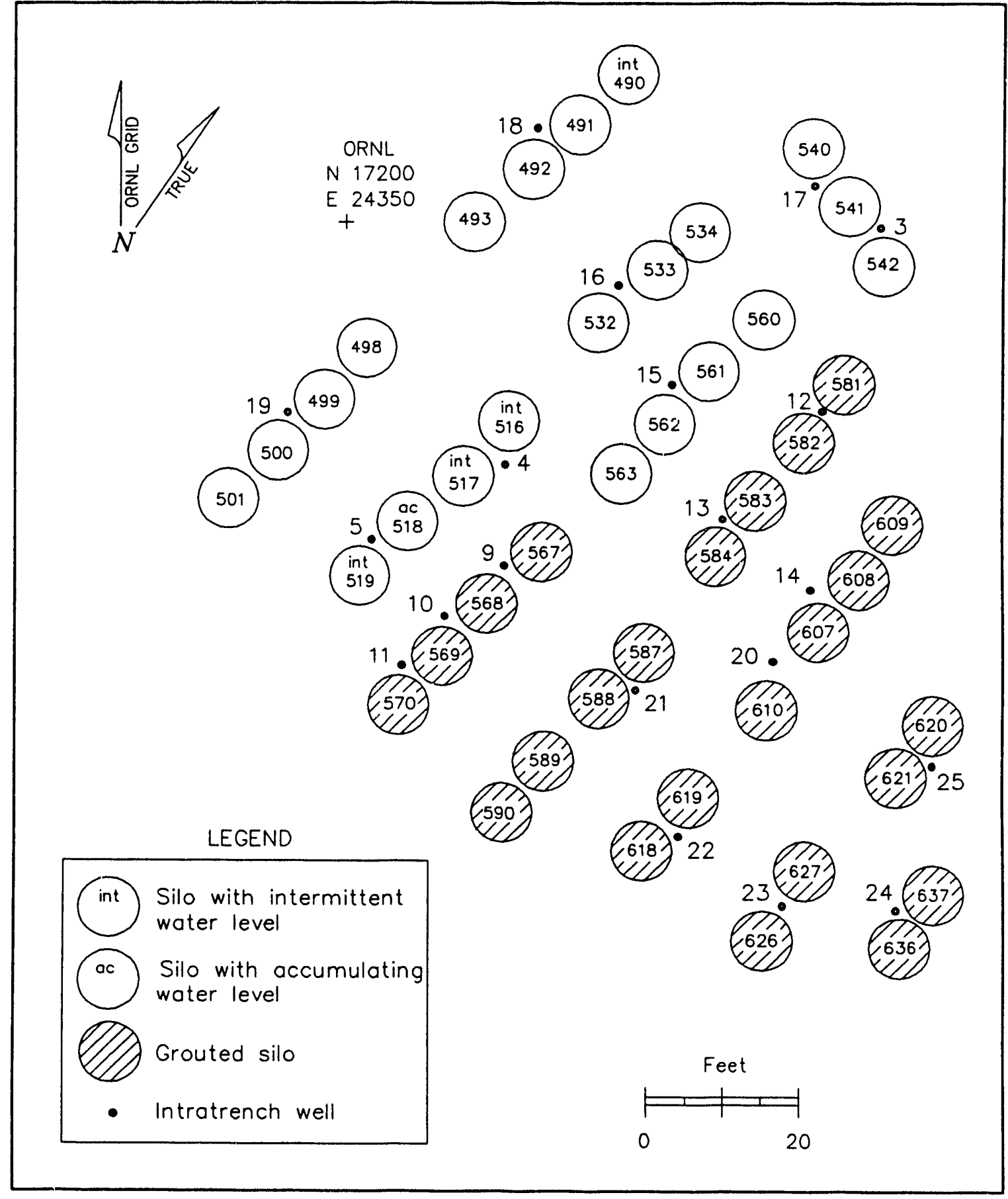

Fig. A.13. Locations of intratrench wells in SWSA 6 low-activity silos area north. 
ORNL-DWG 91-14600

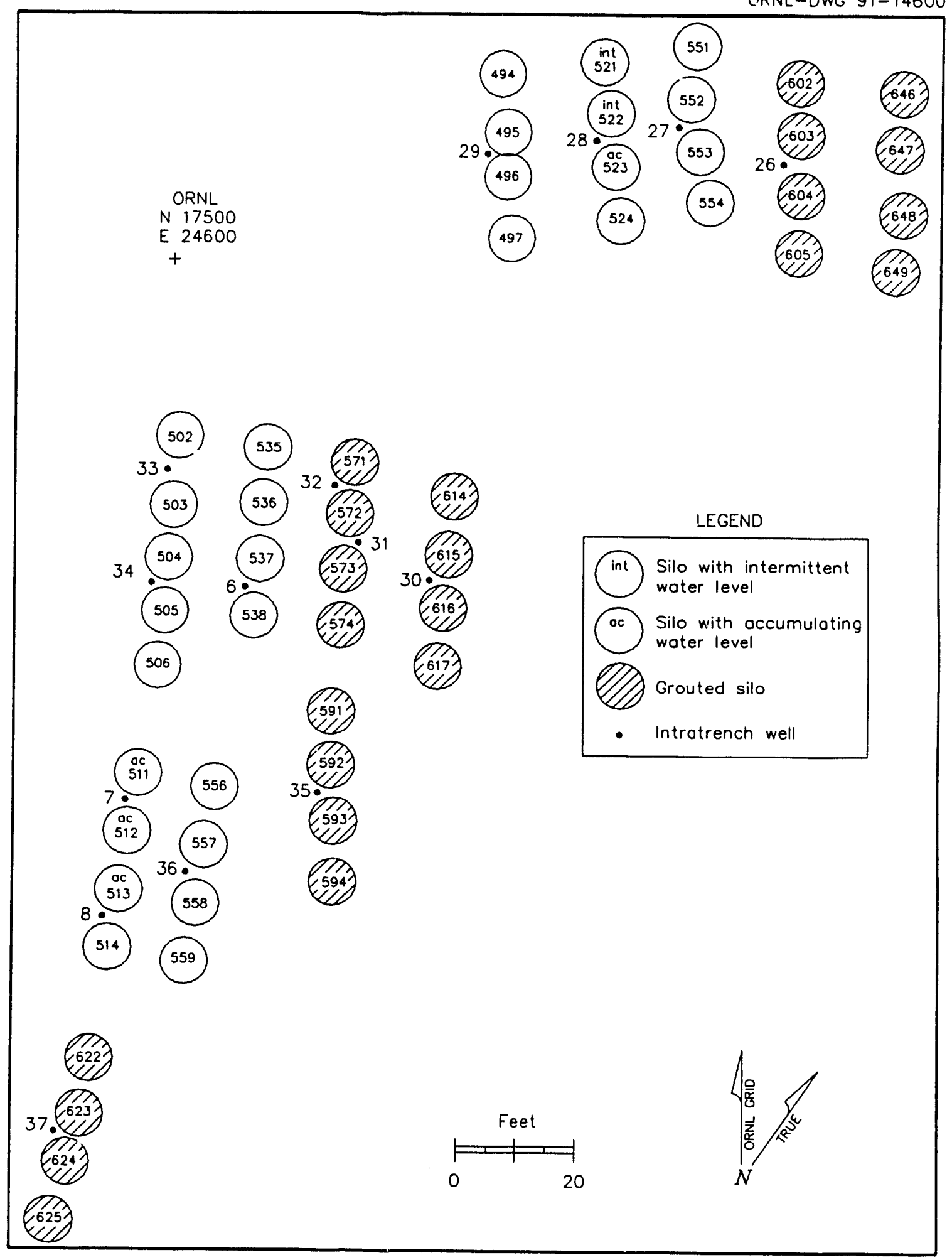

Fig. A.14. Locations of intratrench wells in SWSA 6 high-activity silos area. 


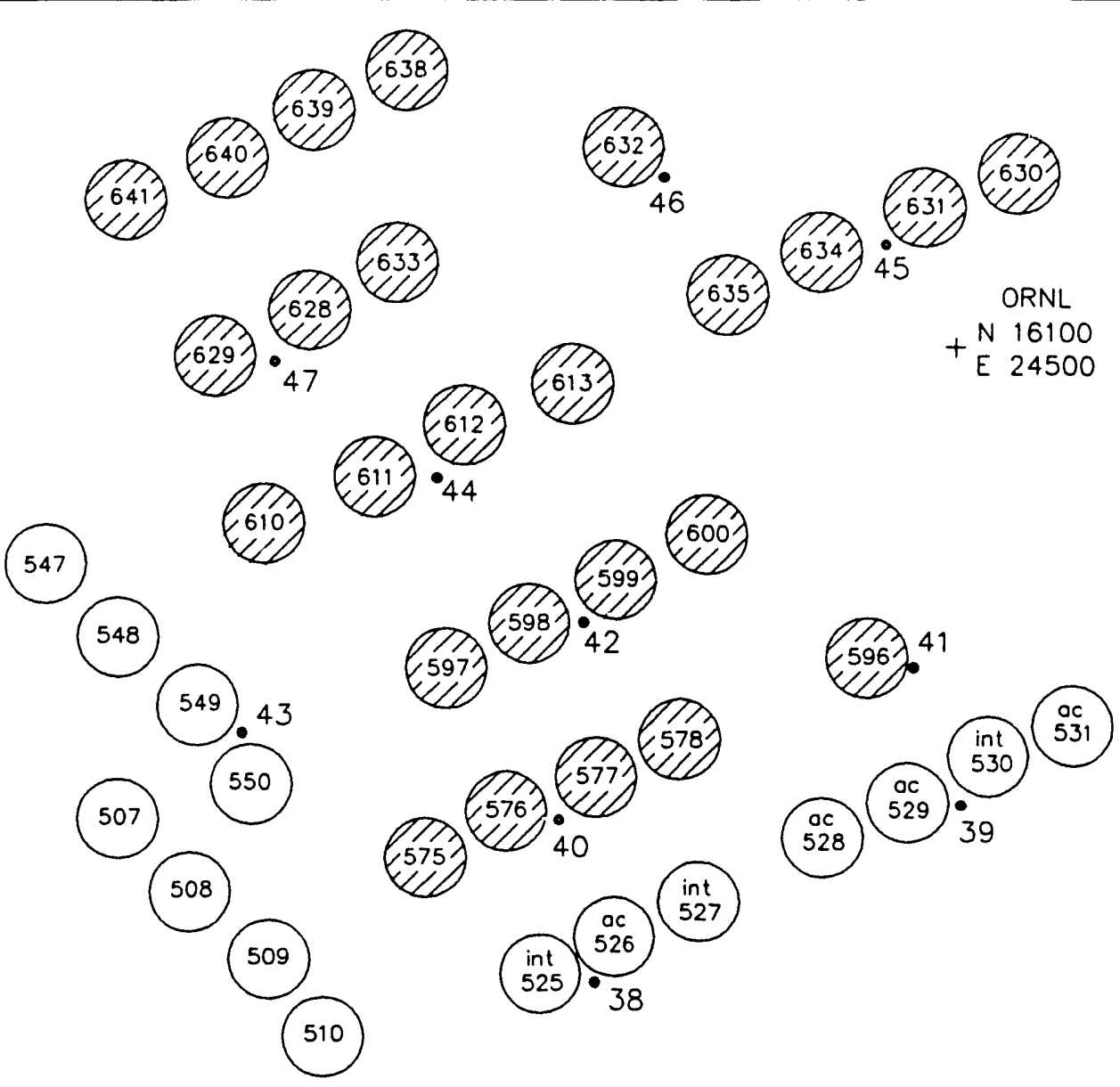

\section{LEGEND}

Silo with intermittent
water level
Silo with occumulating
woter level
Grouted silo
Intratrench well

- Intratrench well

Fig. A.15. Locations of intratrench wells in SWSA 6 low-activity silos area south. 


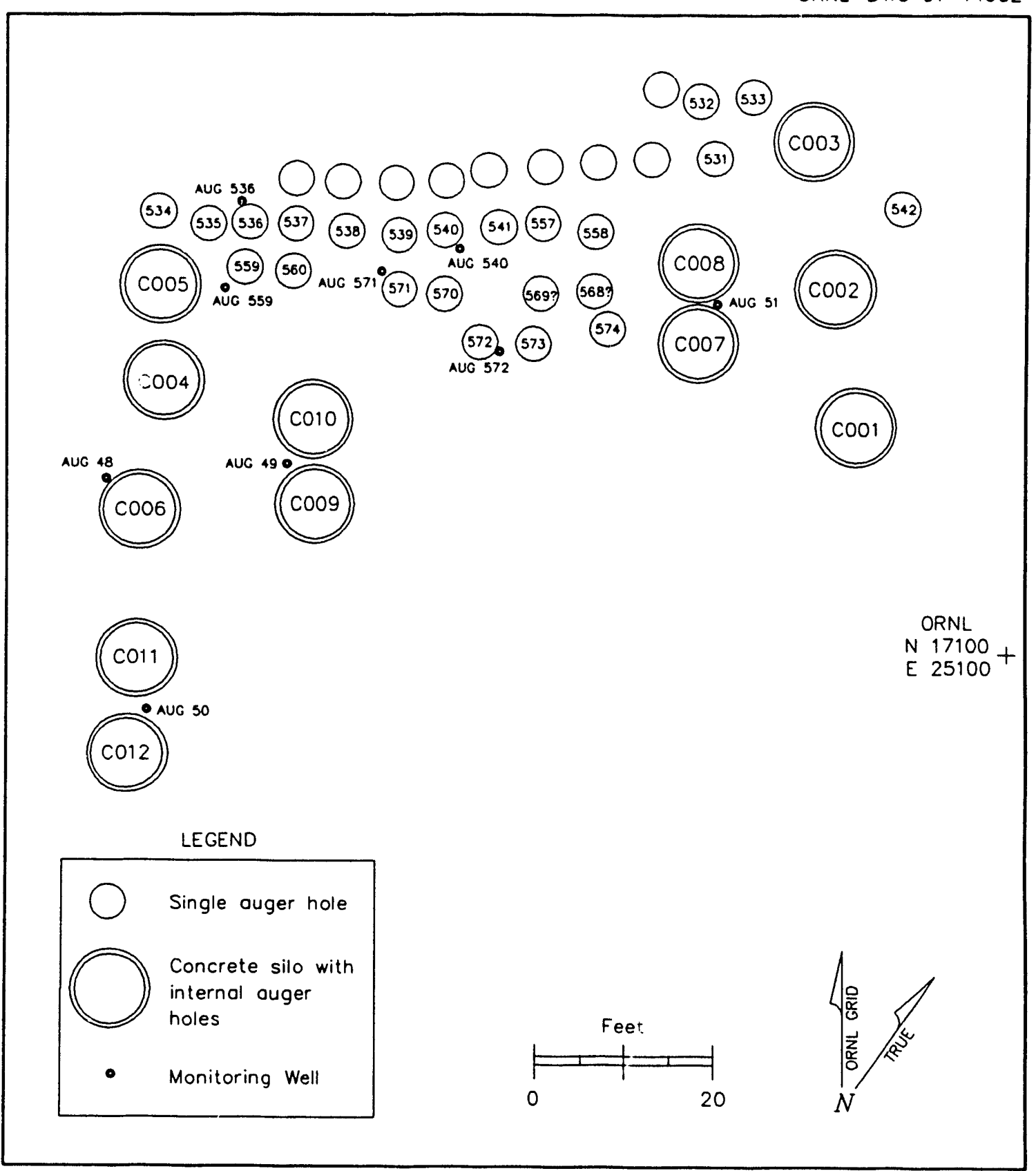

Fig. A.16. Locations of new wells near SWSA 6 high-activity auger holes. 


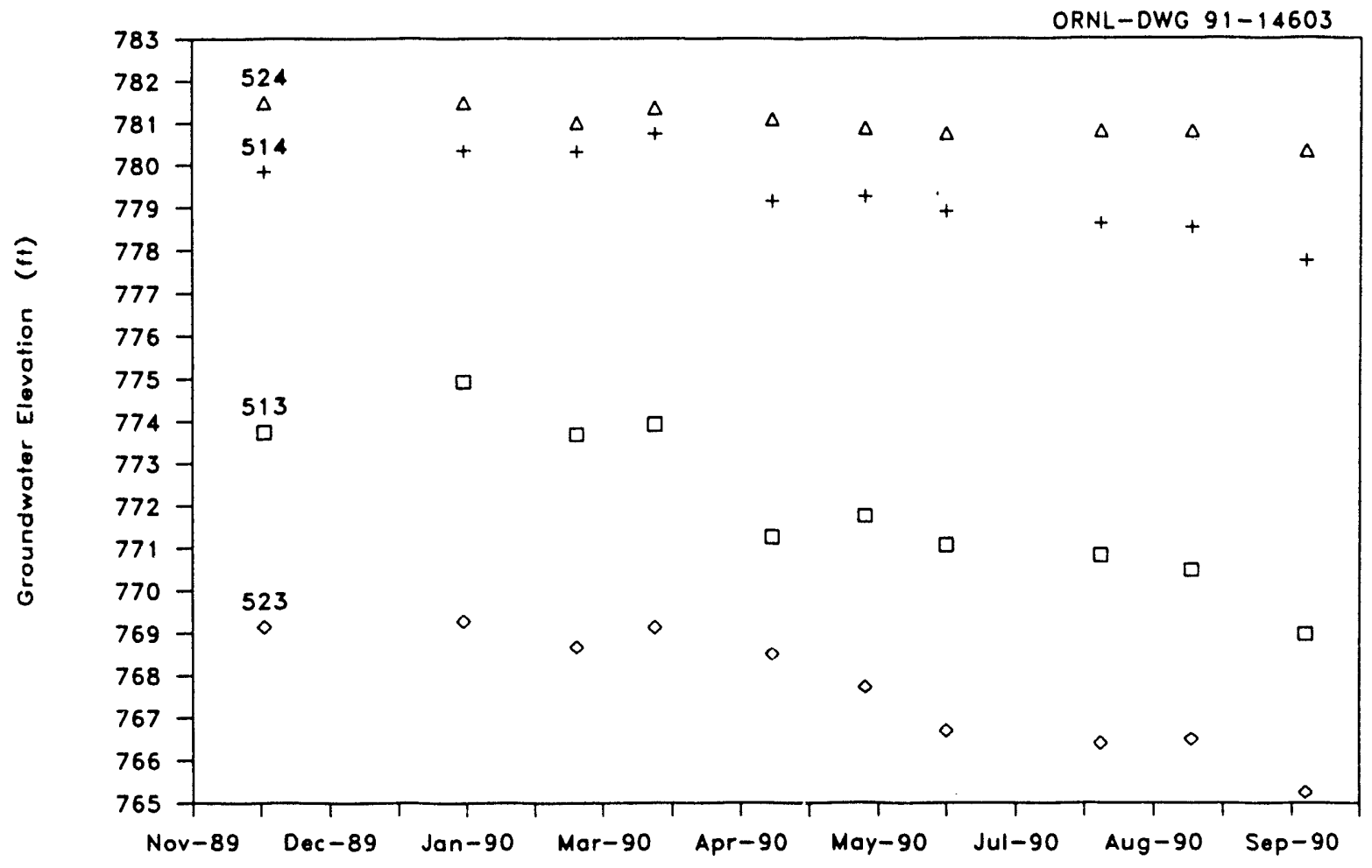

Fig. A.17. SWSA 5 North groundwater elevations in wells $513,514,523$, and 524 .

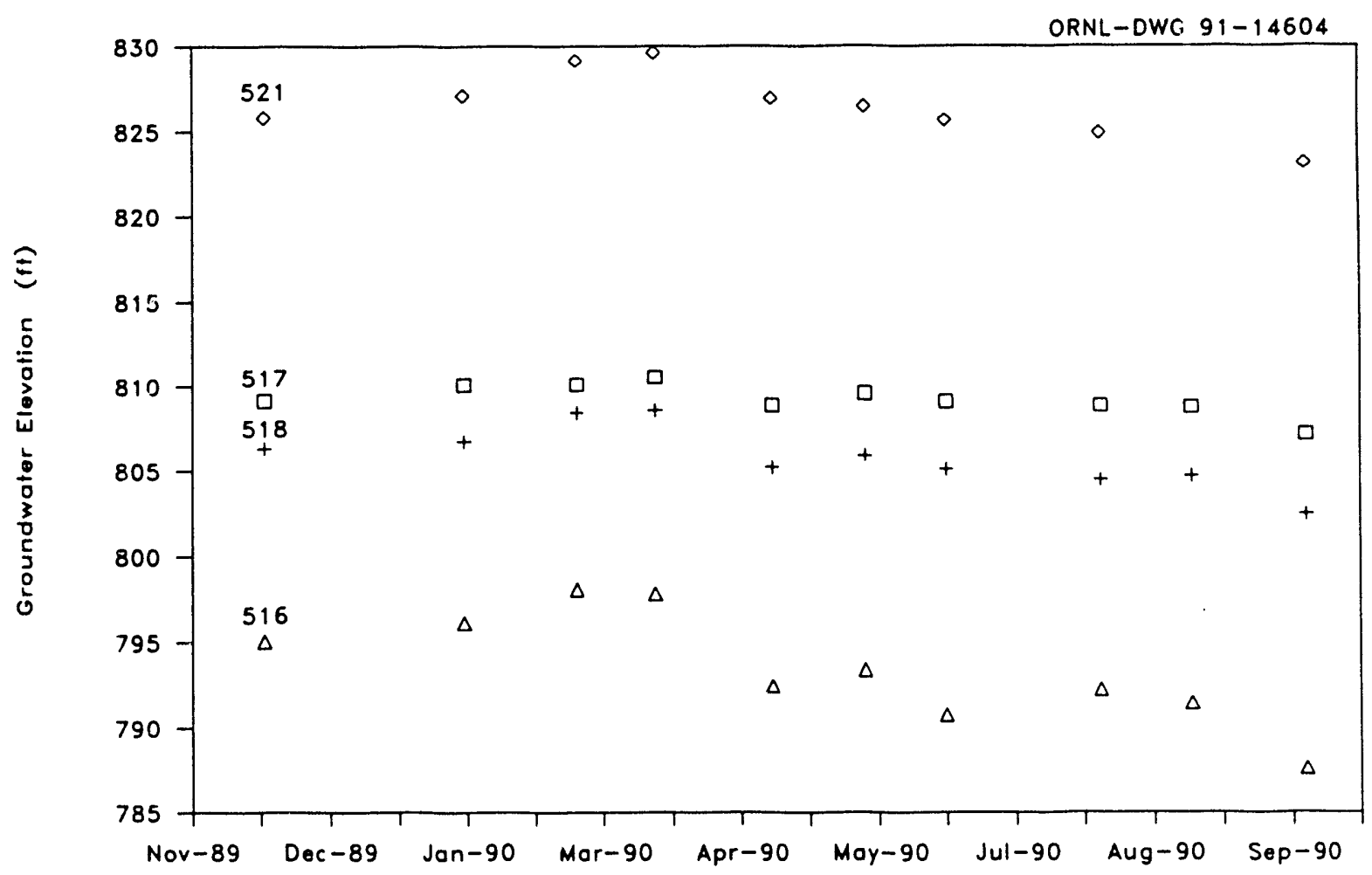

Fig. A.18. SWSA 5 North groundwater elevations in wells $516,517,518$, and 521 . 


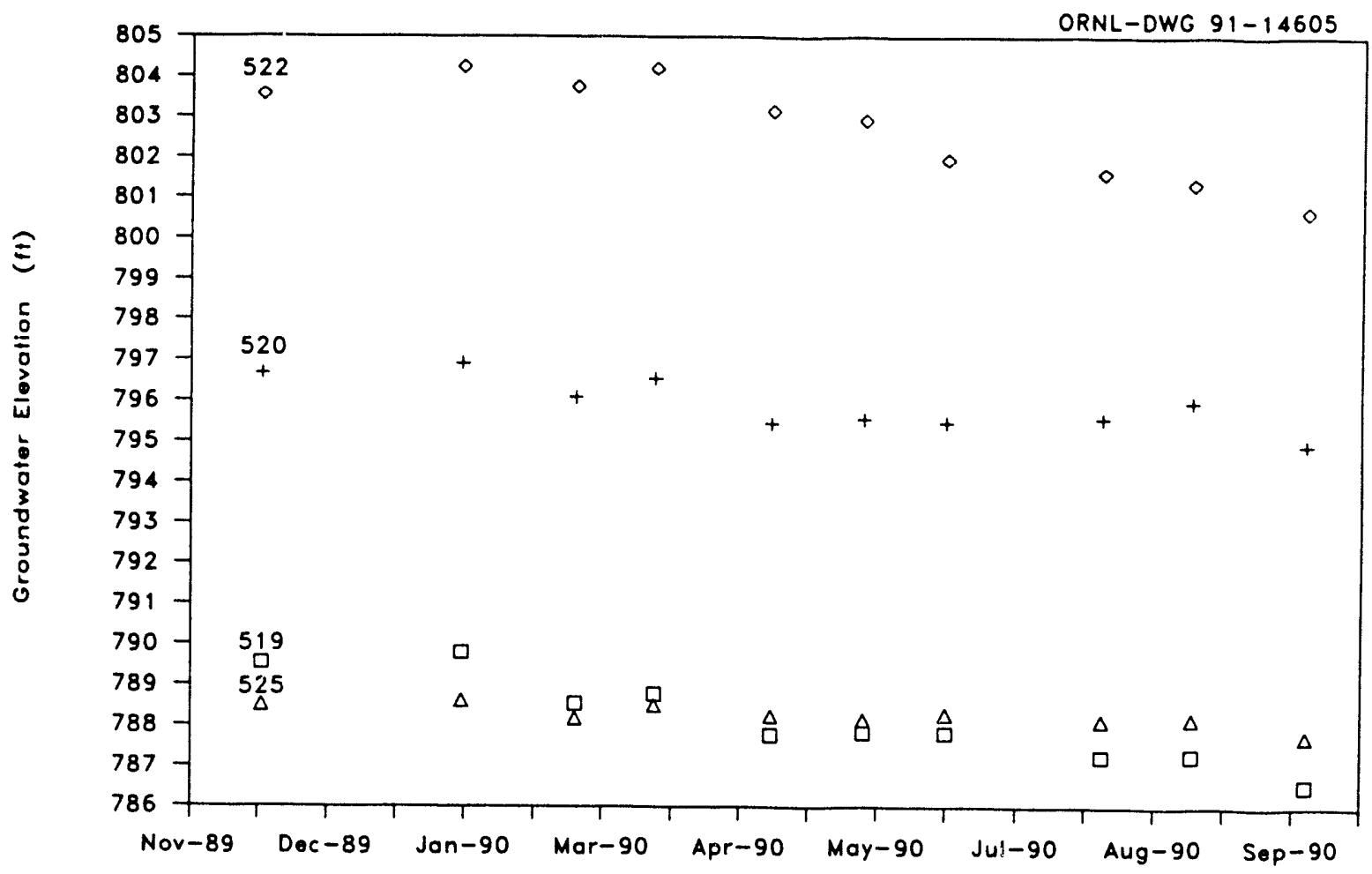

Fig. A.19. SWSA 5 North groundwater elevations in wells $519,520,522$, and 525 .

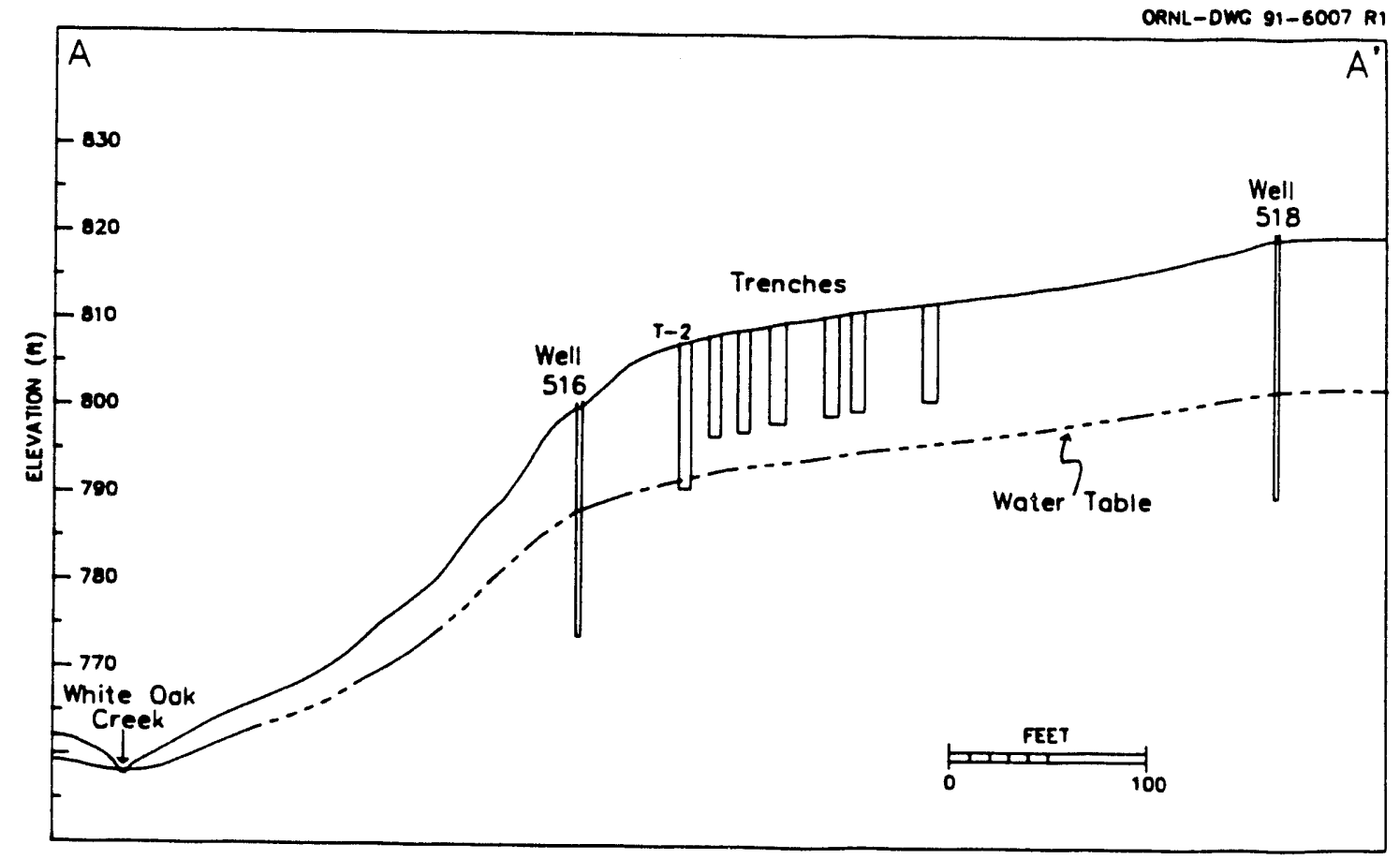

Fig. A.20. Cross section of area between wells 516 and 518 in SWSA 5 North with groundwater elevations for September 1990. 
Appendix B: TABLES

B-1 


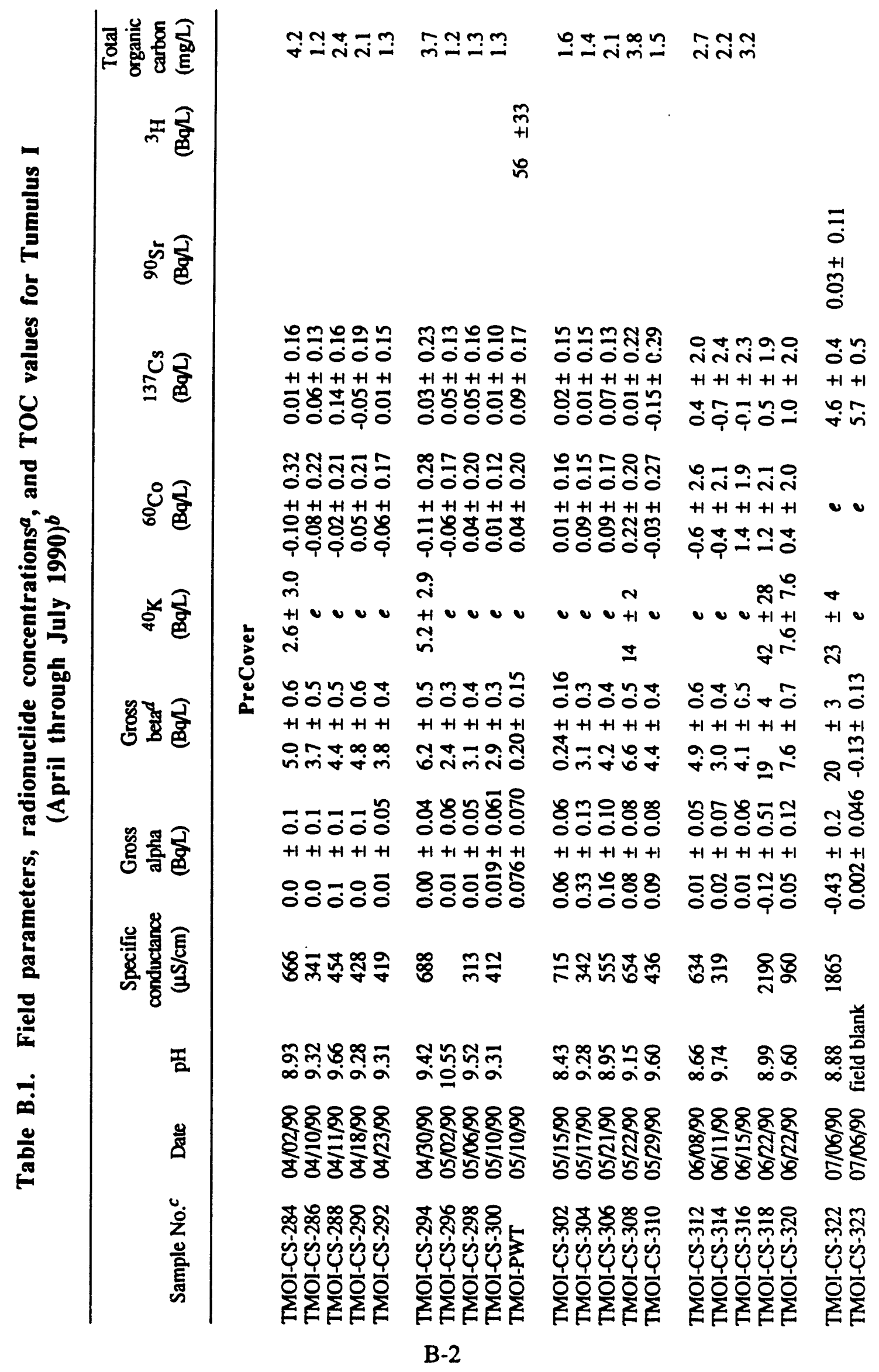




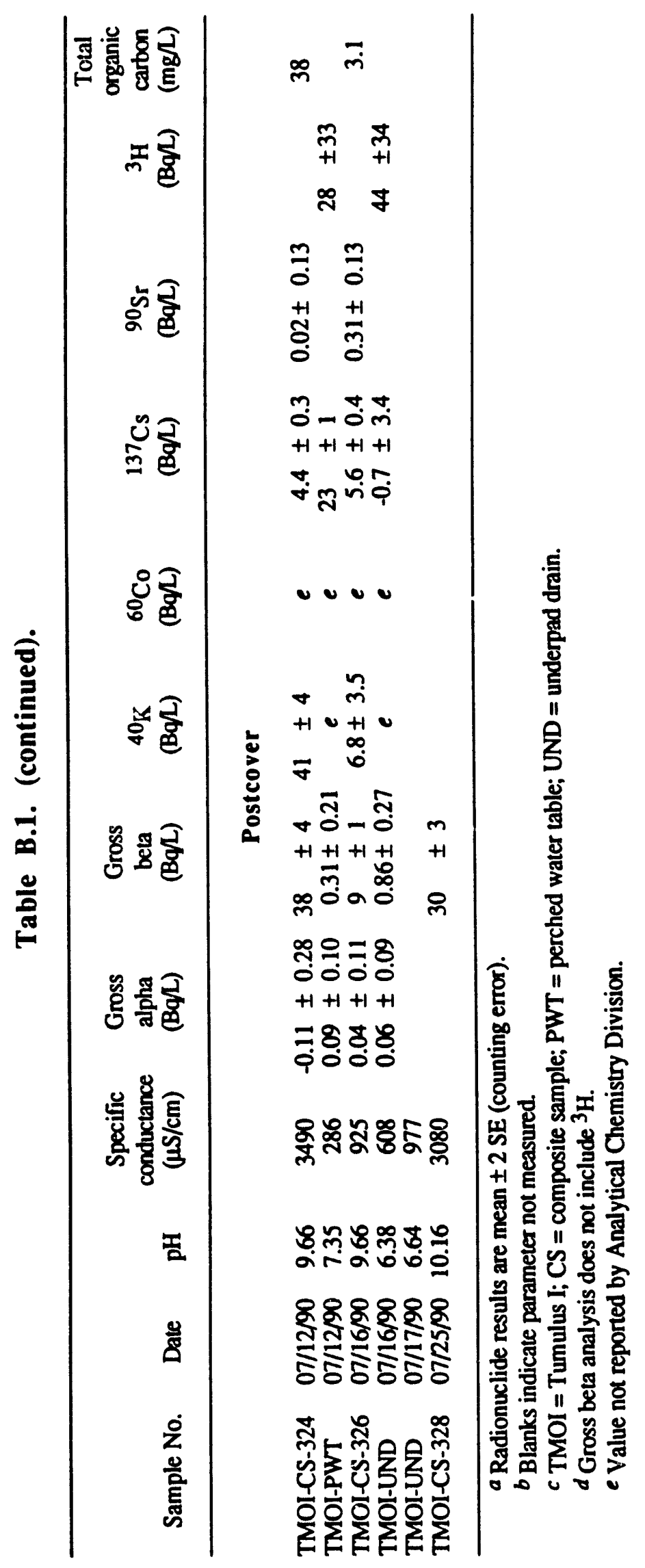

B-3 


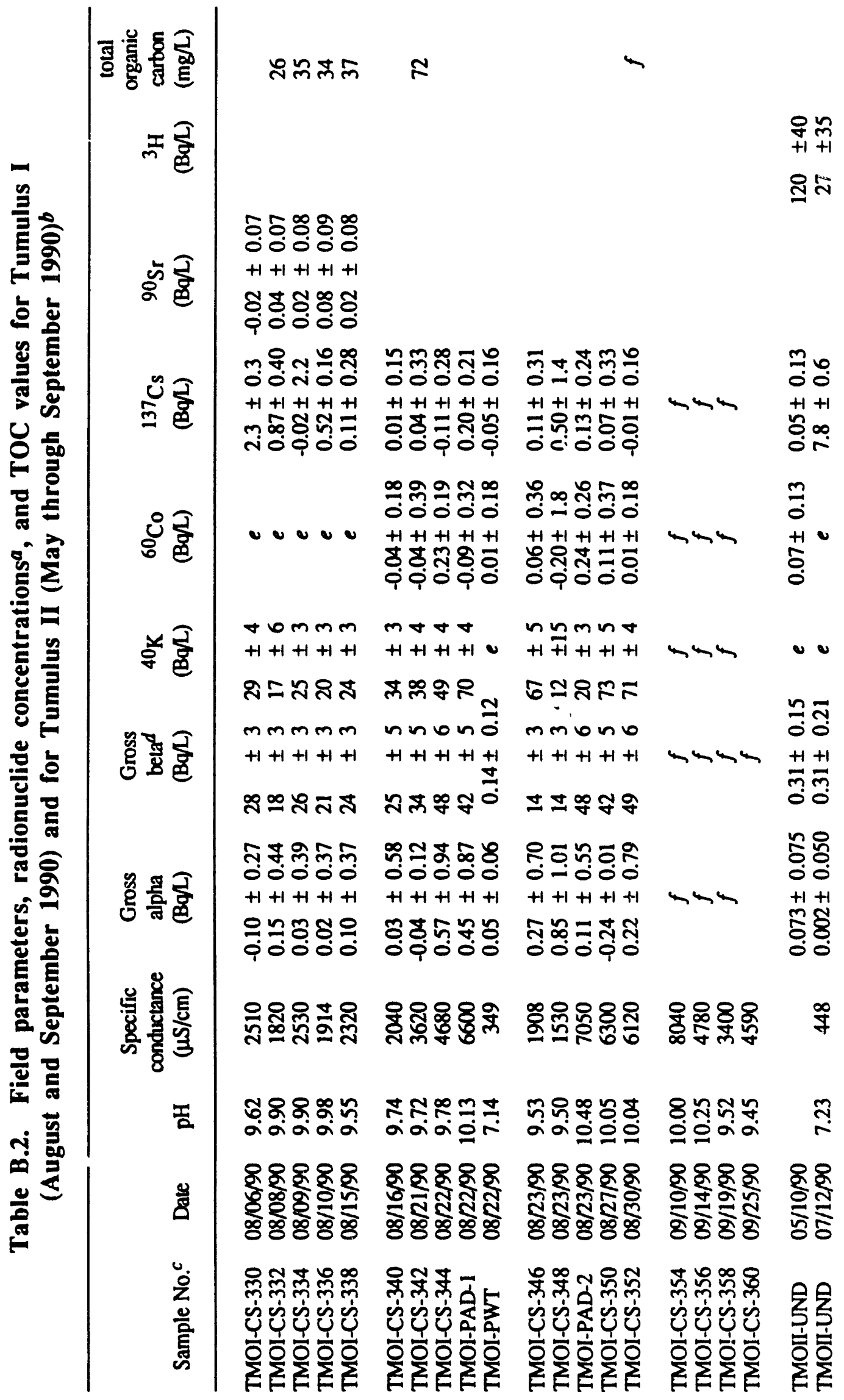




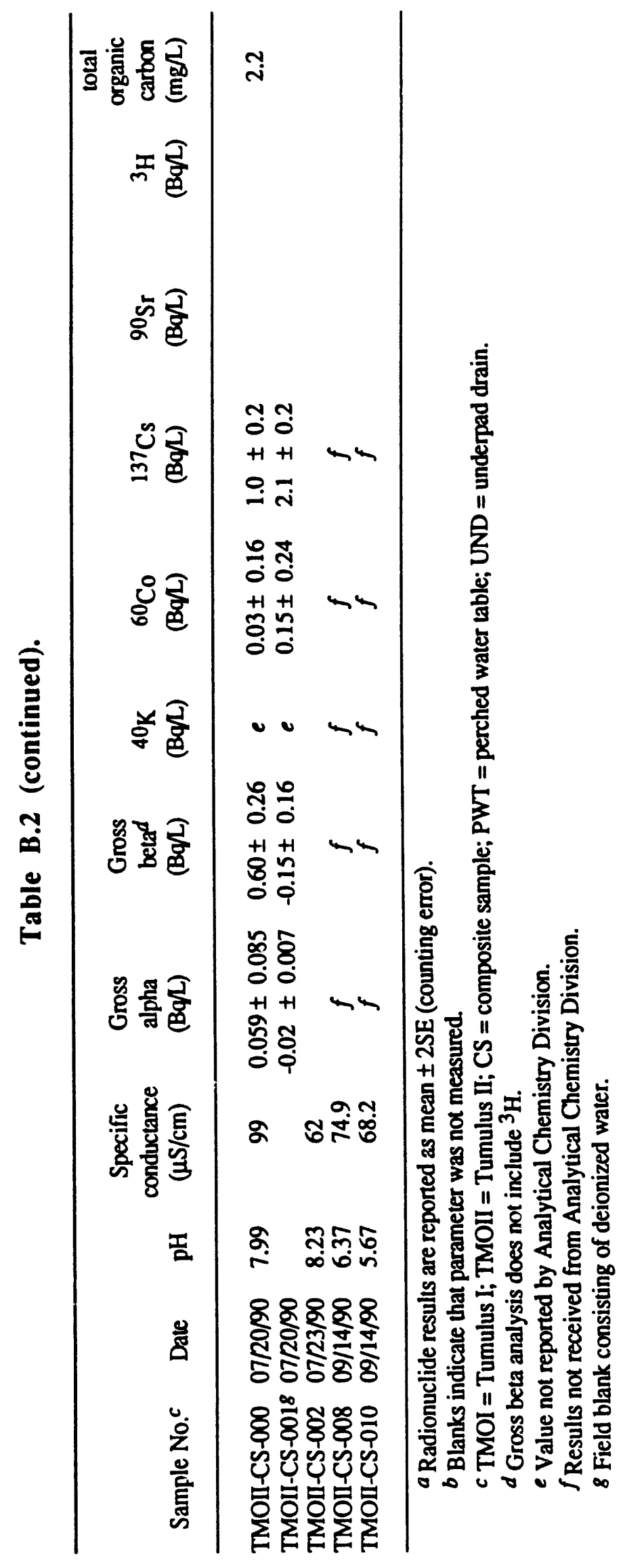




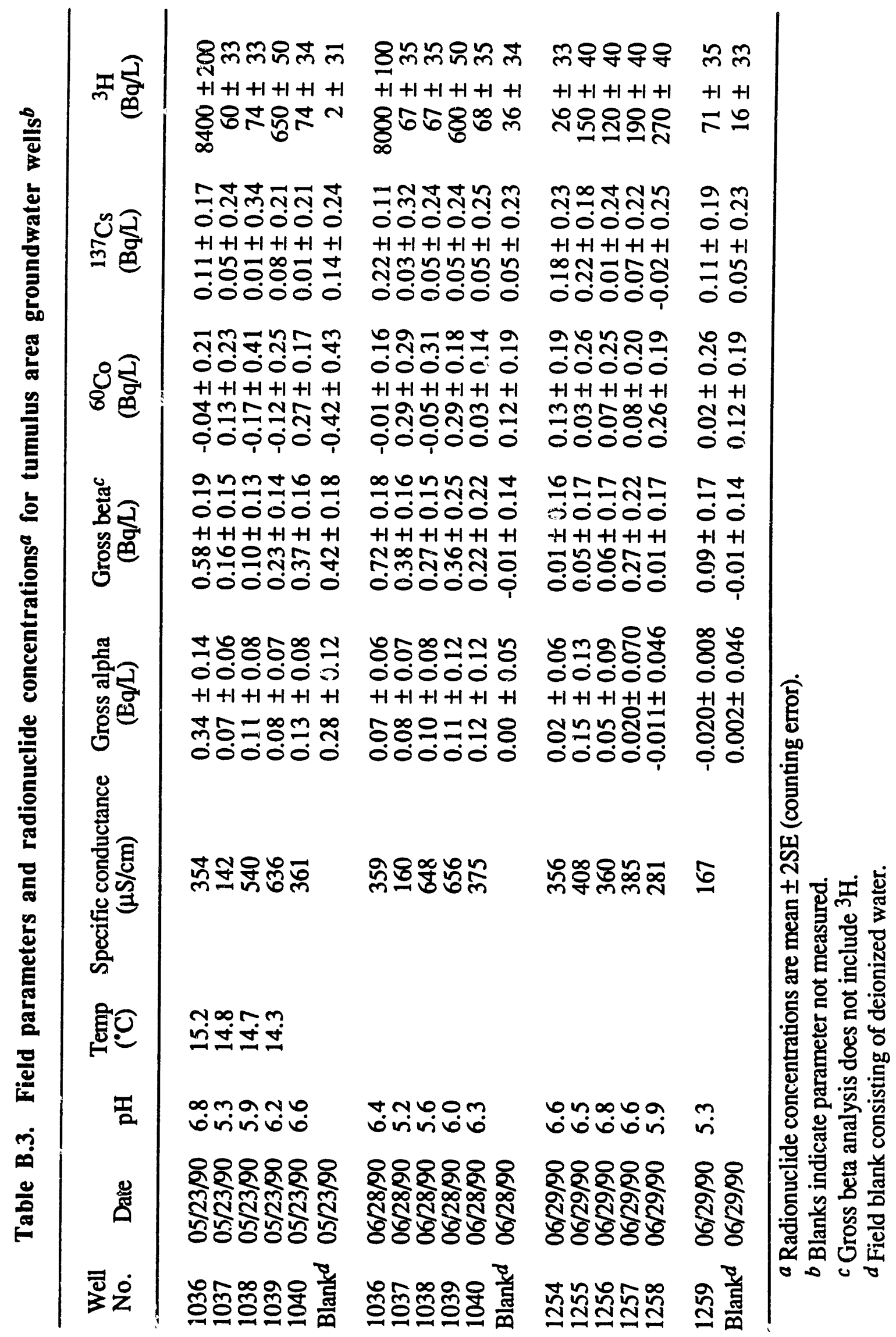

B-6 


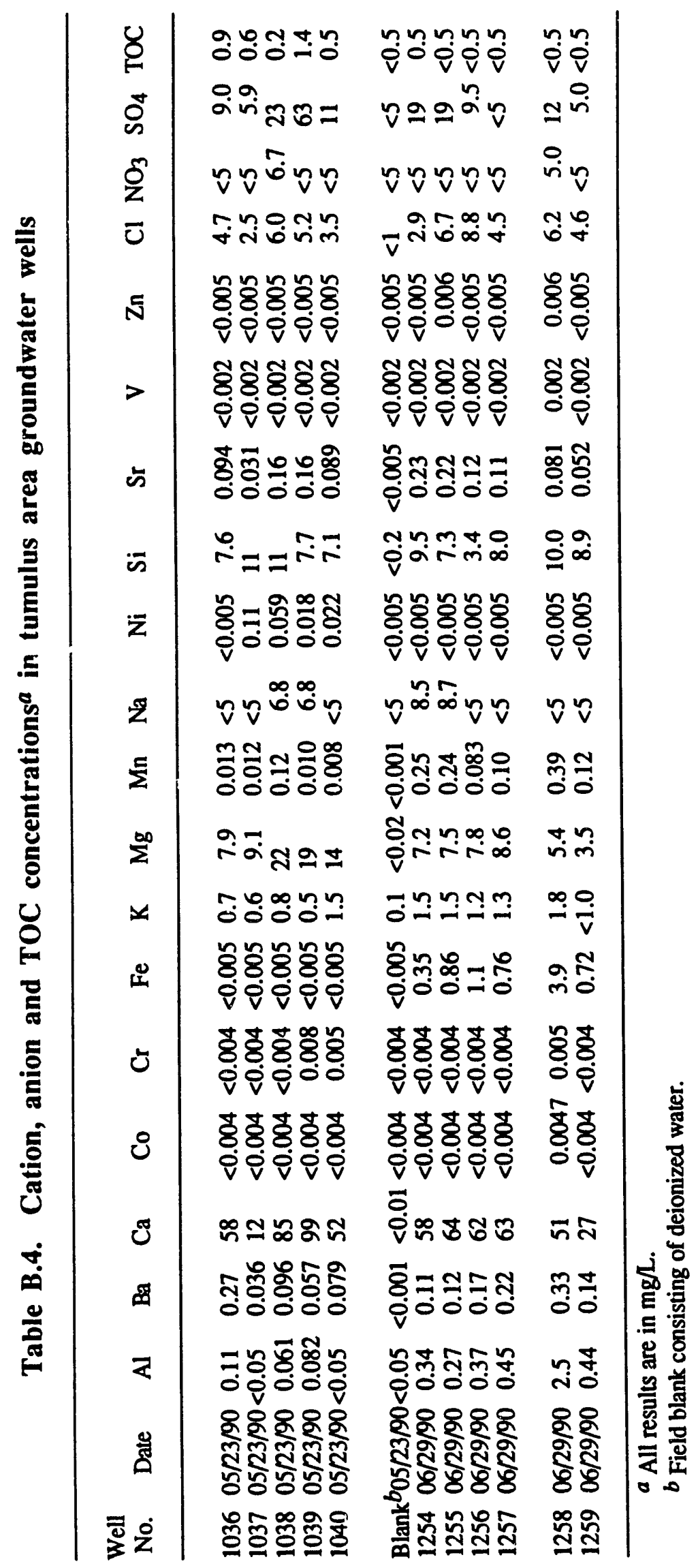

B-7 
Table B.5. Radionuclide concentrations in intratrench wells in SWSA 6 (January through August 1990)

\begin{tabular}{|c|c|c|c|c|c|c|c|c|c|c|c|c|c|}
\hline \multirow{2}{*}{$\frac{\text { Well No }}{12}$} & \multirow{2}{*}{$\begin{array}{c}\text { Date } \\
01 / 16 / 90\end{array}$} & \multicolumn{6}{|c|}{ ESD/HASRD RESULTS ${ }^{a}$} & \multicolumn{6}{|c|}{ ACD RESULTS $b$} \\
\hline & & \multicolumn{3}{|c|}{ Gross Alpha (Bq/L) } & \multicolumn{3}{|c|}{ Gross Beta $(\mathrm{Bq} / \mathrm{L})$} & \multicolumn{3}{|c|}{ Gross Alpha (Bq/L) } & \multicolumn{3}{|c|}{ Gross Beta (Bq/L) } \\
\hline $\begin{array}{r}12 \\
13 \\
5 \\
11 \\
13\end{array}$ & $\begin{array}{l}01 / 16 / 90 \\
01 / 16 / 90 \\
01 / 25 / 90 \\
01 / 25 / 90 \\
01 / 25 / 90\end{array}$ & $\begin{array}{r}0.13 \\
0.01 \\
-0.01 \\
0.03 \\
0.04\end{array}$ & $\begin{array}{l} \pm \\
\pm \\
\pm \\
\pm \\
\pm\end{array}$ & $\begin{array}{l}0.08 \\
0.01 \\
0.03 \\
0.03 \\
0.06\end{array}$ & $\begin{array}{l}0.76 \\
1.82 \\
1.41 \\
0.32 \\
1.58\end{array}$ & $\begin{array}{l} \pm \\
\pm \\
\pm \\
\pm \\
\pm\end{array}$ & $\begin{array}{l}0.15 \\
0.11 \\
0.20 \\
0.06 \\
0.20\end{array}$ & 0.32 & \pm & 0.29 & 3.7 & \pm & 0.8 \\
\hline $\begin{array}{l}4 \\
5 \\
6 \\
7 \\
8\end{array}$ & $\begin{array}{l}02 / 12 / 90 \\
02 / 12 / 90 \\
02 / 12 / 90 \\
02 / 12 / 90 \\
02 / 12 / 90\end{array}$ & $\begin{array}{l}0.08 \\
0.05 \\
0.09 \\
0.06 \\
0.03\end{array}$ & $\begin{array}{l} \pm \\
\pm \\
\pm \\
\pm \\
\pm\end{array}$ & $\begin{array}{l}0.08 \\
0.06 \\
0.09 \\
0.08 \\
0.02\end{array}$ & $\begin{array}{l}0.78 \\
1.17 \\
0.62 \\
0.97 \\
1.88\end{array}$ & $\begin{array}{l} \pm \\
\pm \\
\pm \\
\pm \\
\pm\end{array}$ & $\begin{array}{l}0.15 \\
0.17 \\
0.14 \\
0.17 \\
0.18\end{array}$ & 0.26 & \pm & 0.25 & 2.8 & \pm & 0.7 \\
\hline $\begin{array}{r}11 \\
12 \\
13 \\
4 \\
5\end{array}$ & $\begin{array}{l}02 / 12 / 90 \\
02 / 12 / 90 \\
02 / 12 / 90 \\
06 / 11 / 90 \\
06 / 11 / 90\end{array}$ & $\begin{array}{l}0.02 \\
-0.01 \\
0.03 \\
0.045 \\
0.011\end{array}$ & $\begin{array}{l} \pm \\
\pm \\
\pm \\
\pm \\
\pm\end{array}$ & $\begin{array}{l}0.07 \\
0.06 \\
0.03 \\
0.09 \\
0.01\end{array}$ & $\begin{array}{l}0.69 \\
0.16 \\
2.23 \\
0.82 \\
0.29\end{array}$ & $\begin{array}{l} \pm \\
\pm \\
\pm \\
\pm \\
\pm\end{array}$ & $\begin{array}{l}0.15 \\
0.10 \\
0.20 \\
0.16 \\
0.05\end{array}$ & $\begin{array}{l}\text { C.17 } \\
0.17\end{array}$ & $\begin{array}{l} \pm \\
\pm\end{array}$ & $\begin{array}{l}0.22 \\
0.22\end{array}$ & $\begin{array}{l}0.61 \\
3.4\end{array}$ & \pm & $\begin{array}{l}0.45 \\
0.7\end{array}$ \\
\hline $\begin{array}{r}6 \\
7 \\
8 \\
10 \\
11\end{array}$ & $\begin{array}{l}06 / 11 / 90 \\
06 / 11 / 90 \\
06 / 11 / 90 \\
06 / 11 / 90 \\
06 / 11 / 90\end{array}$ & $\begin{array}{r}0.005 \\
0.040 \\
0.007 \\
-0.038 \\
0.054\end{array}$ & $\begin{array}{l} \pm \\
\pm \\
\pm \\
\pm \\
\pm\end{array}$ & $\begin{array}{l}0.06 \\
0.07 \\
0.02 \\
0.06 \\
0.04\end{array}$ & $\begin{array}{l}0.32 \\
0.25 \\
1.27 \\
0.33 \\
0.32\end{array}$ & $\begin{array}{l} \pm \\
\pm \\
\pm \\
\pm \\
\pm\end{array}$ & $\begin{array}{l}0.11 \\
0.10 \\
0.15 \\
0.12 \\
0.06\end{array}$ & 0.02 & \pm & 0.09 & 0.23 & \pm & 0.34 \\
\hline $\begin{array}{l}12 \\
13 \\
15 \mathrm{~A} \\
15 \mathrm{~B} \\
17\end{array}$ & $\begin{array}{l}06 / 11 / 90 \\
06 / 11 / 90 \\
07 / 25 / 90 \\
07 / 25 / 90 \\
07 / 25 / 90\end{array}$ & $\begin{array}{l}0.001 \\
0.122 \\
0.000 \\
0.000 \\
0.01\end{array}$ & $\begin{array}{l} \pm \\
\pm \\
\pm \\
\pm \\
\pm\end{array}$ & $\begin{array}{l}0.01 \\
0.11 \\
0.007 \\
0.000 \\
0.04\end{array}$ & $\begin{array}{l}0.07 \\
1.54 \\
0.19 \\
0.06 \\
0.37\end{array}$ & $\begin{array}{l} \pm \\
\pm \\
\pm \\
\pm \\
\pm\end{array}$ & $\begin{array}{l}0.03 \\
0.20 \\
0.04 \\
0.01 \\
0.11\end{array}$ & & & & & & \\
\hline $\begin{array}{l}19 \\
20 \\
22 \\
25 \mathrm{~A} \\
25 \mathrm{~B}\end{array}$ & $\begin{array}{l}07 / 25 / 90 \\
07 / 25 / 90 \\
07 / 25 / 90 \\
07 / 25 / 90 \\
07 / 25 / 90\end{array}$ & $\begin{array}{l}0.09 \\
0.06 \\
0.004 \\
0.00 \\
0.002\end{array}$ & $\begin{array}{l} \pm \\
\pm \\
\pm \\
\pm \\
\pm\end{array}$ & $\begin{array}{l}0.03 \\
0.04 \\
0.007 \\
0.00 \\
0.006\end{array}$ & $\begin{array}{r}30.23 \\
0.40 \\
0.20 \\
0.17 \\
0.28\end{array}$ & $\begin{array}{l} \pm \\
\pm \\
\pm \\
\pm \\
\pm\end{array}$ & $\begin{array}{l}0.69 \\
0.08 \\
0.05 \\
0.03 \\
0.05\end{array}$ & $\begin{array}{l}0.34 \\
0.28\end{array}$ & $\begin{array}{l} \pm \\
\pm\end{array}$ & $\begin{array}{l}0.30 \\
0.25\end{array}$ & $\begin{array}{l}60 \\
1.1\end{array}$ & $\begin{array}{l} \pm \\
\pm\end{array}$ & $\begin{array}{l}3 \\
0.5\end{array}$ \\
\hline $\begin{array}{l}26 \\
27 \\
28 \\
30 \\
32\end{array}$ & $\begin{array}{l}07 / 26 / 90 \\
07 / 26 / 90 \\
07 / 26 / 90 \\
07 / 26 / 90 \\
07 / 26 / 90\end{array}$ & $\begin{array}{r}0.03 \\
0.00 \\
0.00 \\
-0.01 \\
0.00\end{array}$ & $\begin{array}{l} \pm \\
\pm \\
\pm \\
\pm \\
\pm\end{array}$ & $\begin{array}{l}0.05 \\
0.00 \\
0.02 \\
0.00 \\
0.00\end{array}$ & $\begin{array}{l}0.23 \\
0.13 \\
0.38 \\
0.27 \\
0.39\end{array}$ & $\begin{array}{l} \pm \\
\pm \\
\pm \\
\pm \\
\pm\end{array}$ & $\begin{array}{l}0.10 \\
0.02 \\
0.08 \\
0.06 \\
0.11\end{array}$ & 0.05 & \pm & 0.14 & 0.80 & \pm & 0.5 \\
\hline $\begin{array}{l}35 \\
38 \\
39 \\
40 \\
41\end{array}$ & $\begin{array}{l}07 / 26 / 90 \\
08 / 03 / 90 \\
08 / 03 / 90 \\
08 / 03 / 90 \\
08 / 03 / 90\end{array}$ & $\begin{array}{l}0.002 \\
0.01 \\
0.02 \\
0.02 \\
0.00\end{array}$ & $\begin{array}{l} \pm \\
\pm \\
\pm \\
\pm \\
\pm\end{array}$ & $\begin{array}{l}0.02 \\
0.00 \\
0.02 \\
0.04 \\
0.02\end{array}$ & $\begin{array}{l}0.37 \\
3.39 \\
0.10 \\
0.18 \\
0.07\end{array}$ & $\begin{array}{l} \pm \\
\pm \\
\pm \\
\pm \\
\pm\end{array}$ & $\begin{array}{l}0.07 \\
0.19 \\
0.04 \\
0.09 \\
0.04\end{array}$ & -0.01 & \pm & 0.11 & 0.63 & \pm & 0.48 \\
\hline $\begin{array}{l}42 \\
43\end{array}$ & $\begin{array}{l}08 / 03 / 90 \\
08 / 03 / 90\end{array}$ & $\begin{array}{l}0.00 \\
0.02\end{array}$ & $\begin{array}{l} \pm \\
\pm\end{array}$ & $\begin{array}{l}0.00 \\
0.03\end{array}$ & $\begin{array}{l}0.09 \\
0.28\end{array}$ & \pm & $\begin{array}{l}0.01 \\
0.09\end{array}$ & 0.58 & \pm & 0.37 & 0.42 & \pm & 0.38 \\
\hline
\end{tabular}

a Analyses performed by ORNL's Environmental Sciences Division (ESD) and Health and Safety Research Division (HASRD). Gross beta analysis does not include ${ }^{3} \mathrm{H}$.

$b$ Analyses performed by ORNL's Analytical Chemistry Division (ACD). Blanks indicate no analyses performed. Gross beta analysis does not include ${ }^{3} \mathrm{H}$. 
Table B.6. Radionuclide concentrations in intratrench wells in SWSA 6 (September 1990) ${ }^{a}$

\begin{tabular}{|c|c|c|c|c|c|}
\hline Well No. & Date & Gross alpha $(\mathrm{Bq} / \mathrm{L})$ & Gross beta $^{b}(\mathrm{~Bq} / \mathrm{L})$ & $137 C$ & $s(B q / L)$ \\
\hline $\begin{array}{r}5 \\
6 \\
7 \\
8 \\
10\end{array}$ & $\begin{array}{l}09 / 20 / 90 \\
09 / 20 / 90 \\
09 / 19 / 90 \\
09 / 19 / 90 \\
09 / 20 / 90\end{array}$ & $\begin{array}{ll}0.16 \pm 0.11 \\
0.049 \pm 0.066 \\
0.015 \pm & 0.044 \\
0.49 \pm & 0.57 \\
0.052 \pm & 0.061\end{array}$ & $\begin{array}{l}0.73 \pm 0.24 \\
0.47 \pm 0.17 \\
0.54 \pm 0.17 \\
2.4 \pm 1.4 \\
0.23 \pm 0.15\end{array}$ & $\begin{array}{r}0.9 \\
-1.2 \\
0.6 \\
0.6 \\
0.4\end{array}$ & $\begin{array}{l} \pm 2.6 \\
\pm 4.9 \\
\pm 1.8 \\
\pm 3.2 \\
\pm 3.7\end{array}$ \\
\hline $\begin{array}{l}11 \\
12 \\
13 \\
15 \\
19\end{array}$ & $\begin{array}{l}09 / 20 / 90 \\
09 / 20 / 90 \\
09 / 20 / 90 \\
09 / 20 / 90 \\
09 / 20 / 90\end{array}$ & $\begin{array}{l}0.027 \pm 0.049 \\
0.057 \pm 0.067 \\
0.7 \pm 1.2 \\
0.11 \pm 0.65 \\
0.72 \pm 0.94\end{array}$ & $\begin{array}{l}0.59 \pm 0.17 \\
0.51 \pm 0.18 \\
9.3 \pm 3.5 \\
0.5 \pm 1.8 \\
50 \quad \pm 6\end{array}$ & $\begin{array}{r}2.4 \\
-0.3 \\
-2.3 \\
0.8 \\
1.4\end{array}$ & $\begin{array}{l} \pm 1.9 \\
\pm 3.8 \\
\pm 6.9 \\
\pm 2.6 \\
\pm 3.5\end{array}$ \\
\hline $\begin{array}{l}25 \\
27 \\
28 \\
30 \\
32\end{array}$ & $\begin{array}{l}09 / 20 / 90 \\
09 / 20 / 90 \\
09 / 20 / 90 \\
09 / 20 / 90 \\
09 / 20 / 90\end{array}$ & $\begin{array}{ll}0.08 \pm & 0.07 \\
0.073 \pm & 0.085 \\
0.029 \pm & 0.054 \\
0.041 \pm & 0.067 \\
-0.33 \pm & 0.13\end{array}$ & $\begin{array}{l}0.29 \pm 0.18 \\
0.69 \pm 0.20 \\
0.63 \pm 0.18 \\
0.38 \pm 0.16 \\
0.8 \pm 1.7\end{array}$ & $\begin{array}{r}-0.8 \\
2.0 \\
2.0 \\
0.3 \\
-0.4\end{array}$ & $\begin{array}{l} \pm 4.1 \\
\pm 5.9 \\
\pm 4.9 \\
\pm 3.8 \\
\pm \quad 5.7\end{array}$ \\
\hline $\begin{array}{l}35 \\
36 \\
38 \\
42\end{array}$ & $\begin{array}{l}09 / 20 / 90 \\
09 / 20 / 90 \\
09 / 20 / 90 \\
09 / 20 / 90\end{array}$ & $\begin{array}{ll}0.49 \pm & 0.82 \\
1.4 \pm 1.3 \\
0.02 \pm & 0.50 \\
0.091 \pm & 0.094\end{array}$ & $\begin{array}{c}2.2 \pm 1.9 \\
-0.2 \pm 2.0 \\
4.5 \pm 2.4 \\
0.89 \pm 0.21\end{array}$ & $\begin{array}{r}0.2 \\
2.4 \\
-0.7 \\
0.3\end{array}$ & $\begin{array}{l} \pm 2.6 \\
\pm 5.9 \\
\pm 3.8 \\
\pm 4.1\end{array}$ \\
\hline
\end{tabular}

a All analyses performed by ORNL's Analytical Chemistry Division.

$b$ Gross beta analysis does not include ${ }^{3} \mathrm{H}$. 
Table B.7. Results from ${ }^{90} \mathrm{Sr}$ and ${ }^{3} \mathrm{H}$ analyses of samples from intratrench wells in SWSA 6

\begin{tabular}{cccc}
\hline Well No. & Date & $90 \mathrm{Sr}(\mathrm{Bq} / \mathrm{L})$ & $3 \mathrm{H}^{a}(\mathrm{~Bq} / \mathrm{L})$ \\
\hline 13 & $01 / 16 / 90$ & $0.13 \pm 0.33$ & $30 \pm 34$ \\
5 & $02 / 12 / 90$ & & $-4 \pm 33$ \\
13 & $06 / 11 / 90$ & $0.09 \pm 0.27$ & \\
8 & $09 / 19 / 90$ & $0.54 \pm 0.44$ & \\
38 & $09 / 20 / 90$ & $1.3 \pm 0.6$ & \\
\hline
\end{tabular}

$a$ Blanks indicate analysis not performed. 


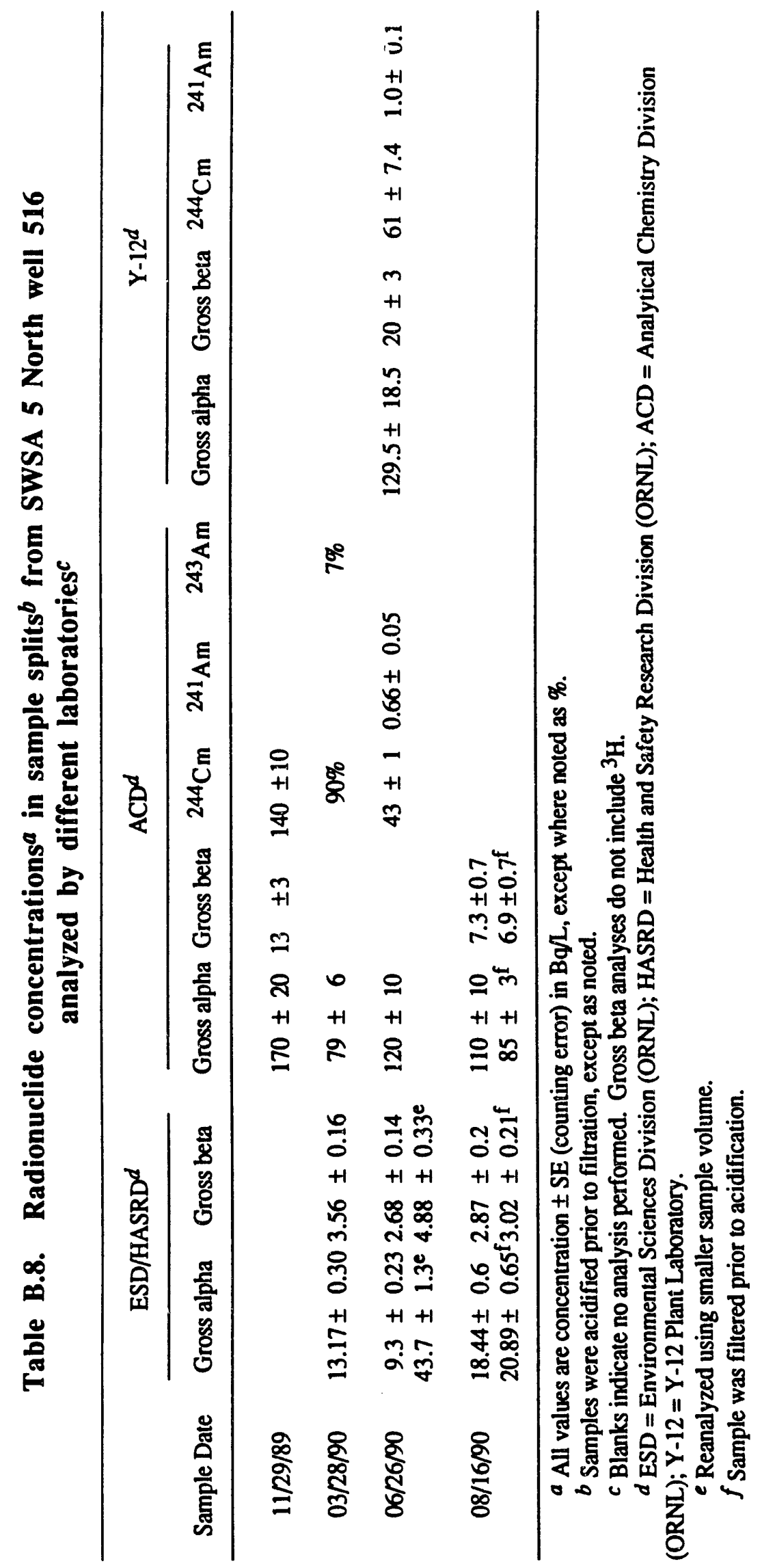

B-11 
Table B.9. Radionuclide concentrations ${ }^{a}$ in water samples from quarterly sampling of streams and seeps near SWSA 5 North

\begin{tabular}{lcccccccc}
\hline Location & Source & Date & 60 Co & 137 Cs & Gross alpha & Gross beta $b$ & 3H \\
\hline 5NN 01 & stream & $03 / 07 / 90$ & $c$ & $c$ & $-0.004 \pm 0.026$ & $0.14 \pm 0.05$ & $52 \pm 35$ \\
5NN 02 & stream & $03 / 07 / 90$ & $c$ & $c$ & $0.02 \pm 0.03$ & $0.19 \pm 0.05$ & $40 \pm 34$ \\
5NS 01 & seep & $03 / 07 / 90$ & $c$ & $c$ & $0.39 \pm 0.18$ & $1.15 \pm 0.18$ & $150 \pm 40$ \\
5NS 02 & stream & $03 / 07 / 90$ & $c$ & $c$ & $3.93 \pm 0.50$ & $3.45 \pm 0.29$ & $970 \pm 60$ \\
5NW 01 & seep & $03 / 07 / 90$ & $c$ & $c$ & $0.11 \pm 0.12$ & $0.58 \pm 0.14$ & $610 \pm 50$ \\
5NW 02 & seep & $03 / 07 / 90$ & $c$ & $c$ & $0.04 \pm 0.11$ & $0.11 \pm 0.10$ & $350 \pm 40$ \\
5NN 01 & stream & $06 / 26 / 90$ & $c$ & $c$ & $0.02 \pm 0.03$ & $0.23 \pm 0.05$ & $d$ \\
$5 N N 02$ & stream & $06 / 26 / 90$ & $c$ & $c$ & $0.01 \pm 0.03$ & $0.20 \pm 0.05$ & $d$ \\
\hline
\end{tabular}

a Concentration $\pm \mathrm{SE}$ (counting error) in $\mathrm{Bq} / \mathrm{L}$.

$b$ Gross beta analysis does not include ${ }^{3} \mathrm{H}$.

$c$ Concentration was below minimum detectable activity of $\sim 2.5 \mathrm{~Bq} / \mathrm{L}$.

$d$ Analysis not performed. 
Table B.10. Radionuclide concentrations ${ }^{a}$ in sediment samples from quarterly sampling of streams and seeps near SWSA 5 North

\begin{tabular}{|c|c|c|c|c|c|c|c|}
\hline Location & Source & Date & & Co-60 & Cs- 137 & Gross alpha & Gross beta $b$ \\
\hline $5 \mathrm{NN} 02$ & stream & $03 / 07 / 90$ & & $.1 \pm 0.3$ & $12 \pm 0.7$ & $230 \pm 220$ & $850 \pm 360$ \\
\hline 5NS 01 & seep & 03/07/90 & 33 & \pm 1.3 & $147 \pm 1.8$ & $1600 \pm 600$ & $2700 \pm 600$ \\
\hline $5 \mathrm{NS} 02$ & stream & $03 / 07 / 90$ & 42 & \pm 2.4 & $164 \pm 3.2$ & $1000 \pm 400$ & $2500 \pm 400$ \\
\hline $5 \mathrm{NW} 01$ & seep & 03/07/90 & & $c$ & $32 \pm 1.5$ & $380 \pm 270$ & $930 \pm 350$ \\
\hline $5 N W 02$ & seep & 03/07/90 & & $c$ & $28 \pm 1.0$ & $200 \pm 220$ & $1000 \pm 400$ \\
\hline $5 \mathrm{NN} 02$ & stream & $06 / 26 / 90$ & & $c$ & $19 \pm 2.3$ & $250 \pm 150$ & $640 \pm 230$ \\
\hline $5 \mathrm{NN} 02$ & stream & $09 / 13 / 90$ & & $c$ & $17 \pm 2.4$ & $380 \pm 260$ & $720 \pm 280$ \\
\hline
\end{tabular}




\title{
Appendix C:
}

\section{TUMULUS AREA WELL LOGS}

\author{
Prepared by \\ Environmental Consulting Engineers, Inc. \\ under \\ Subcontract No. 17X-SC924C
}




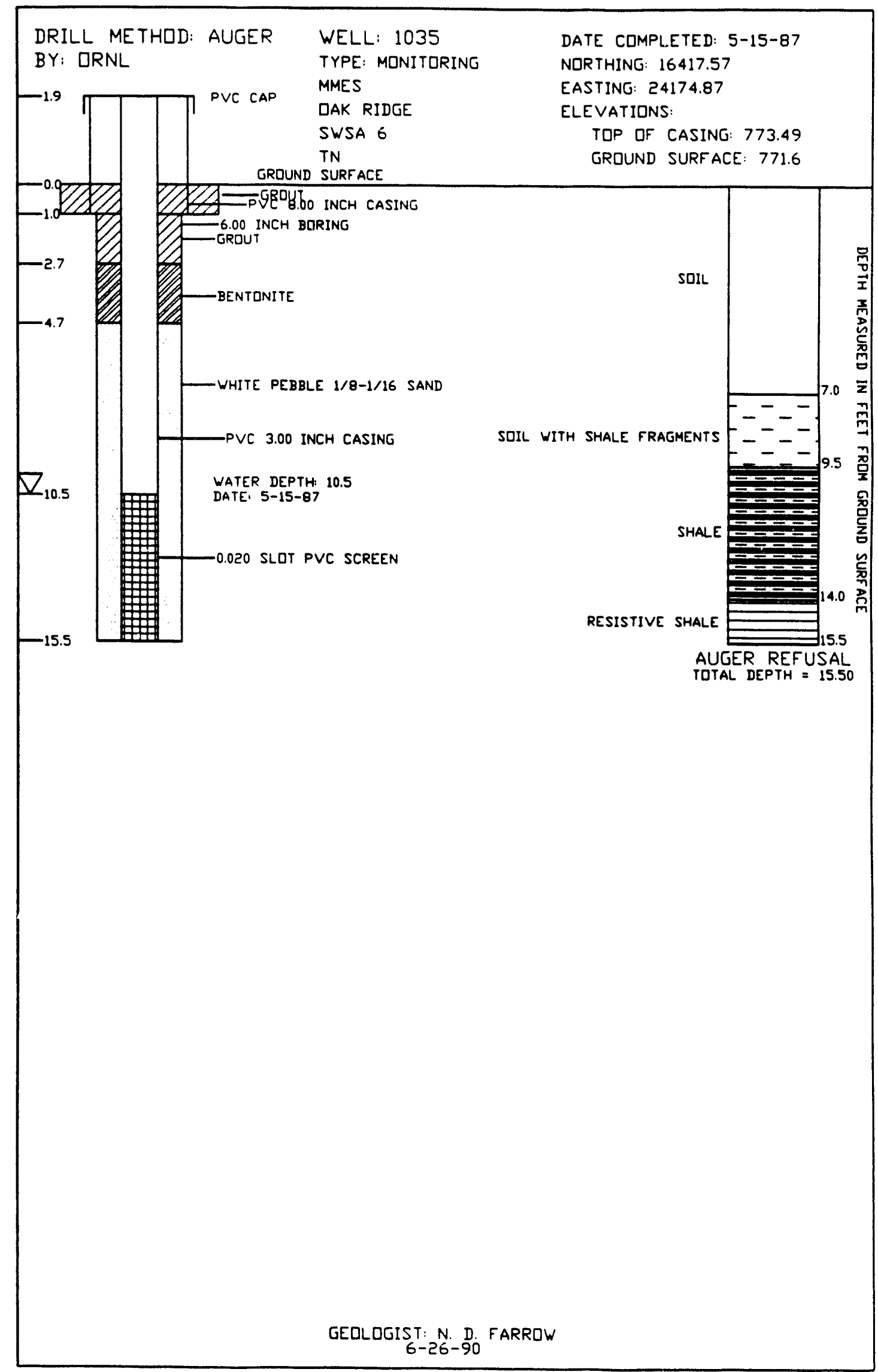

C-2 


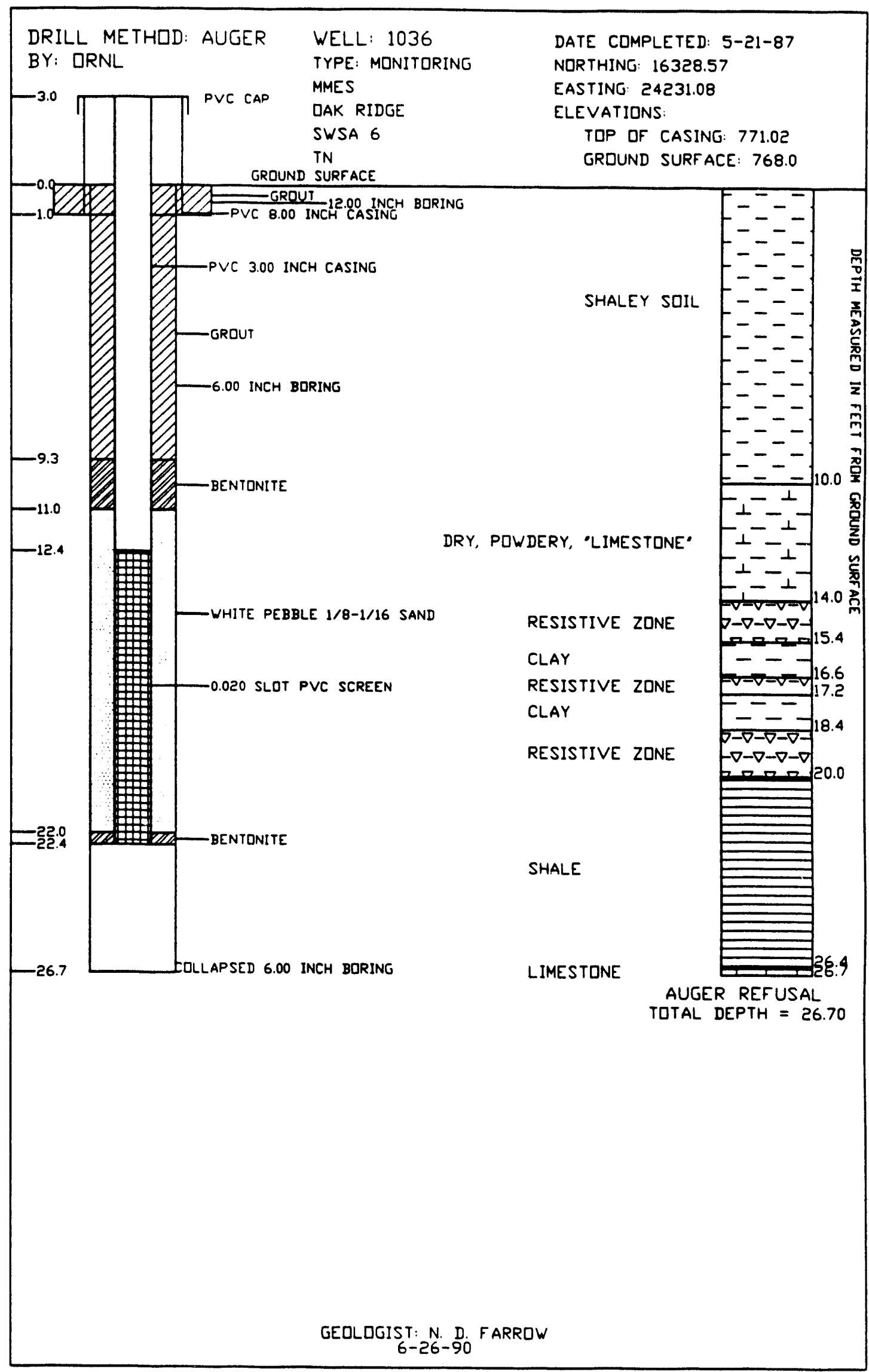

C-3 


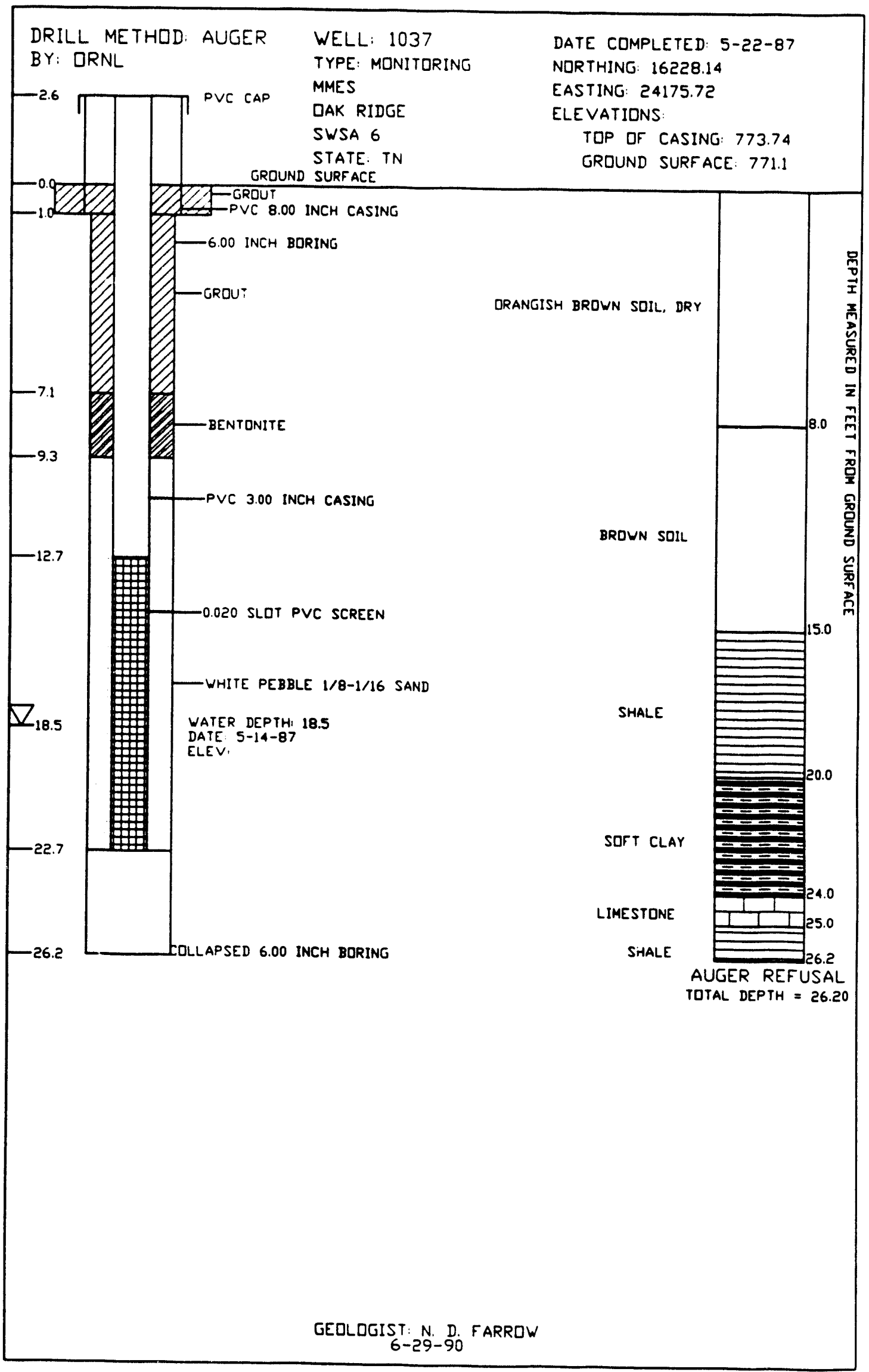




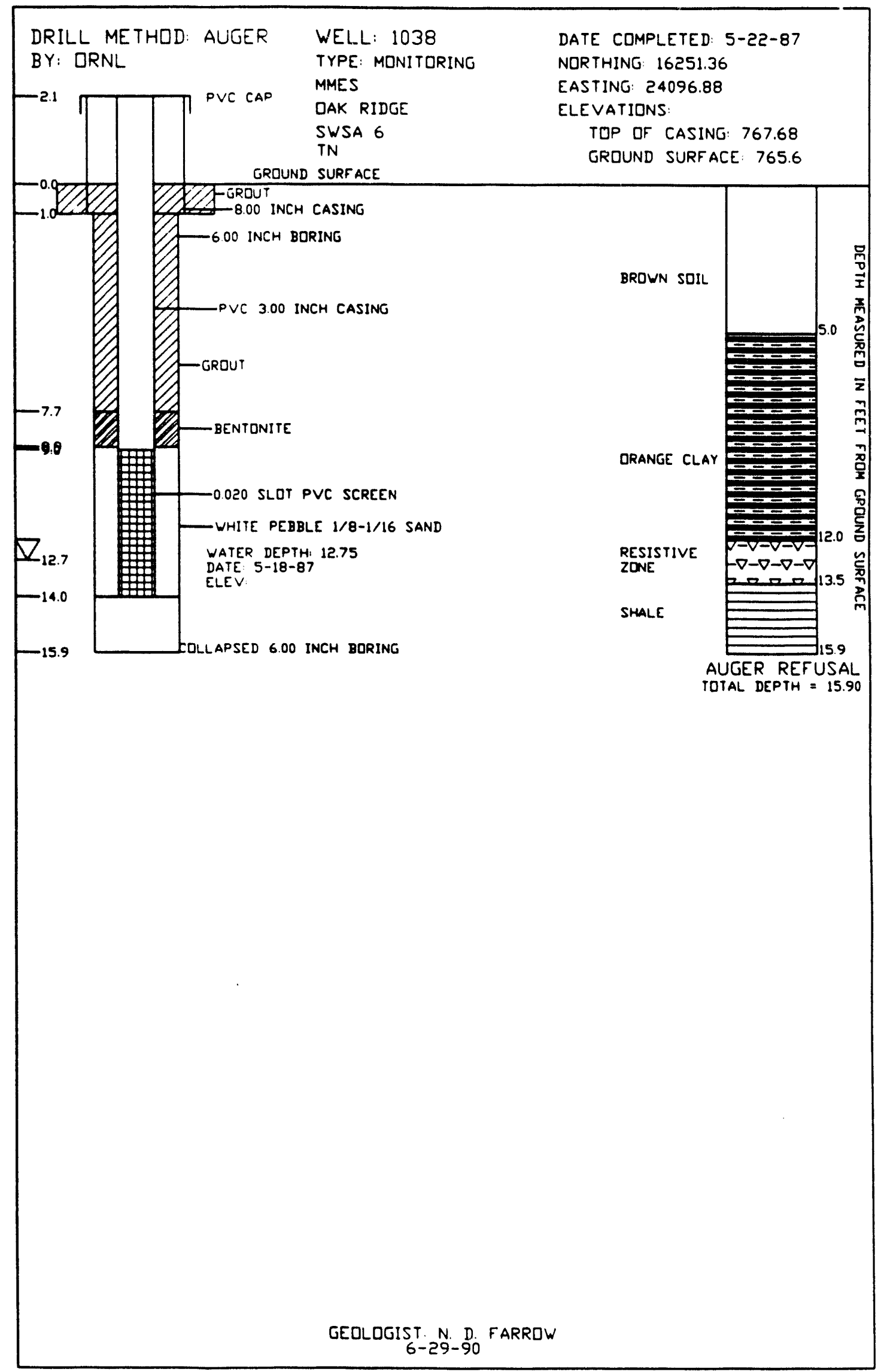

C-5 


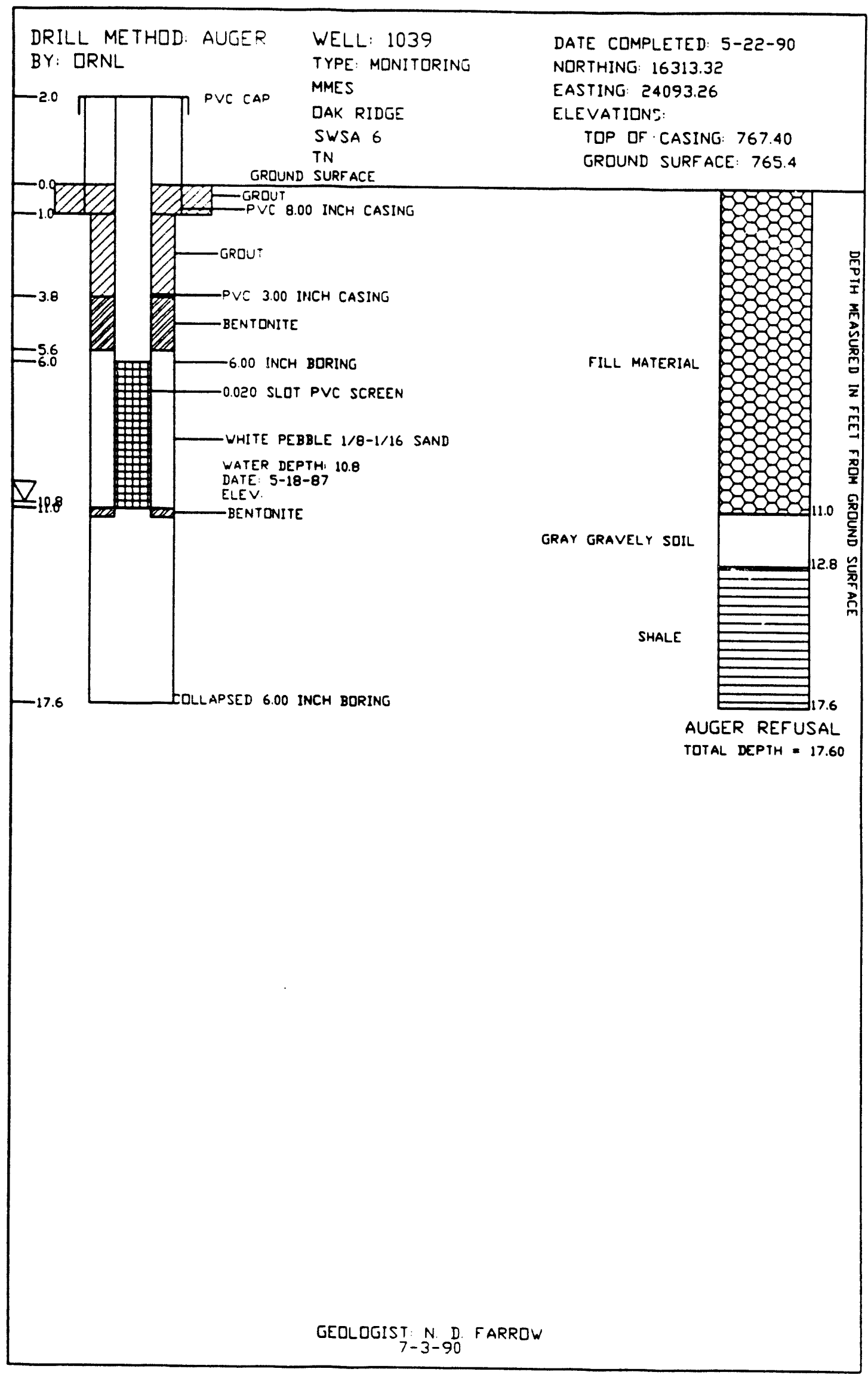




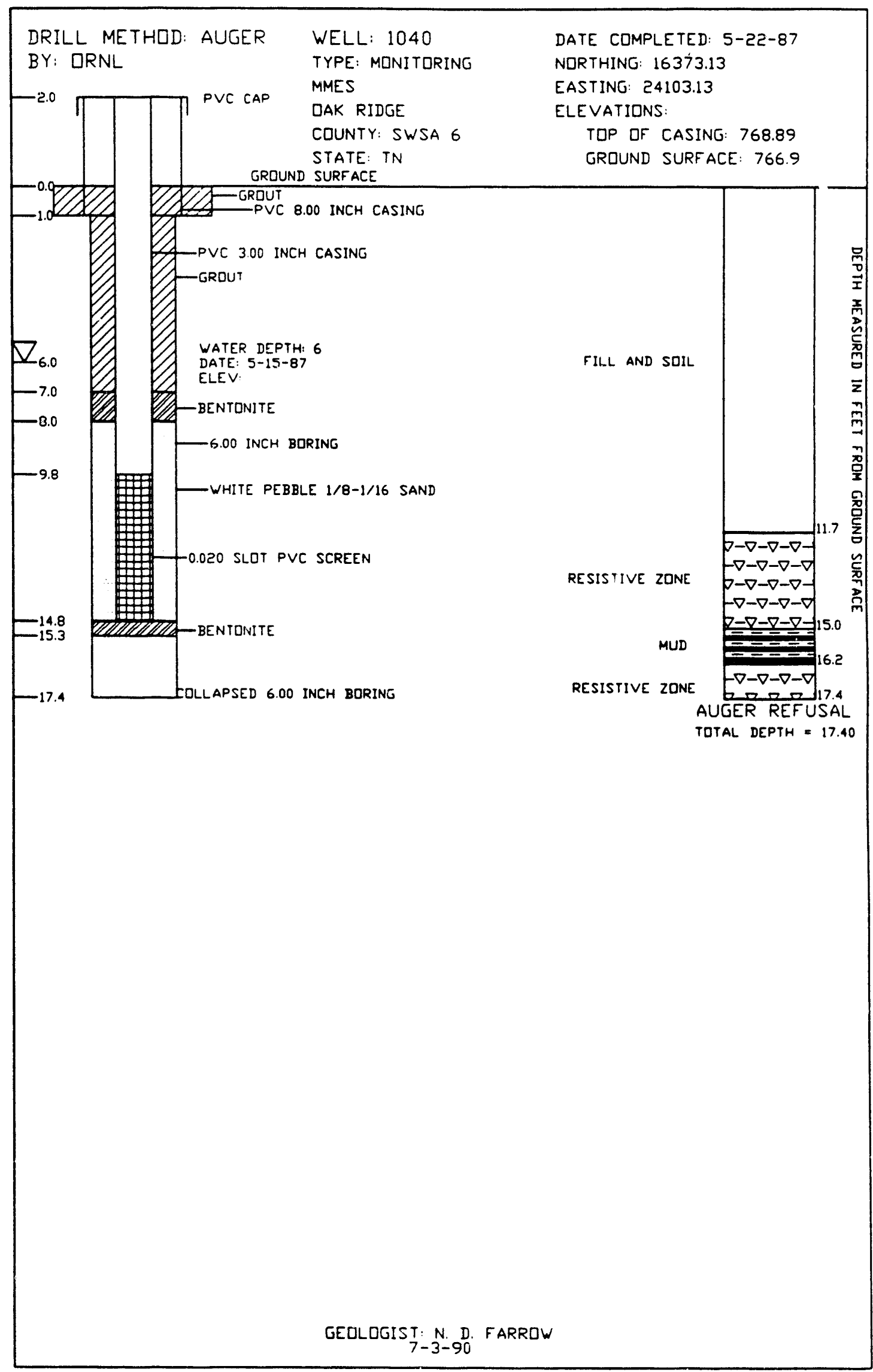




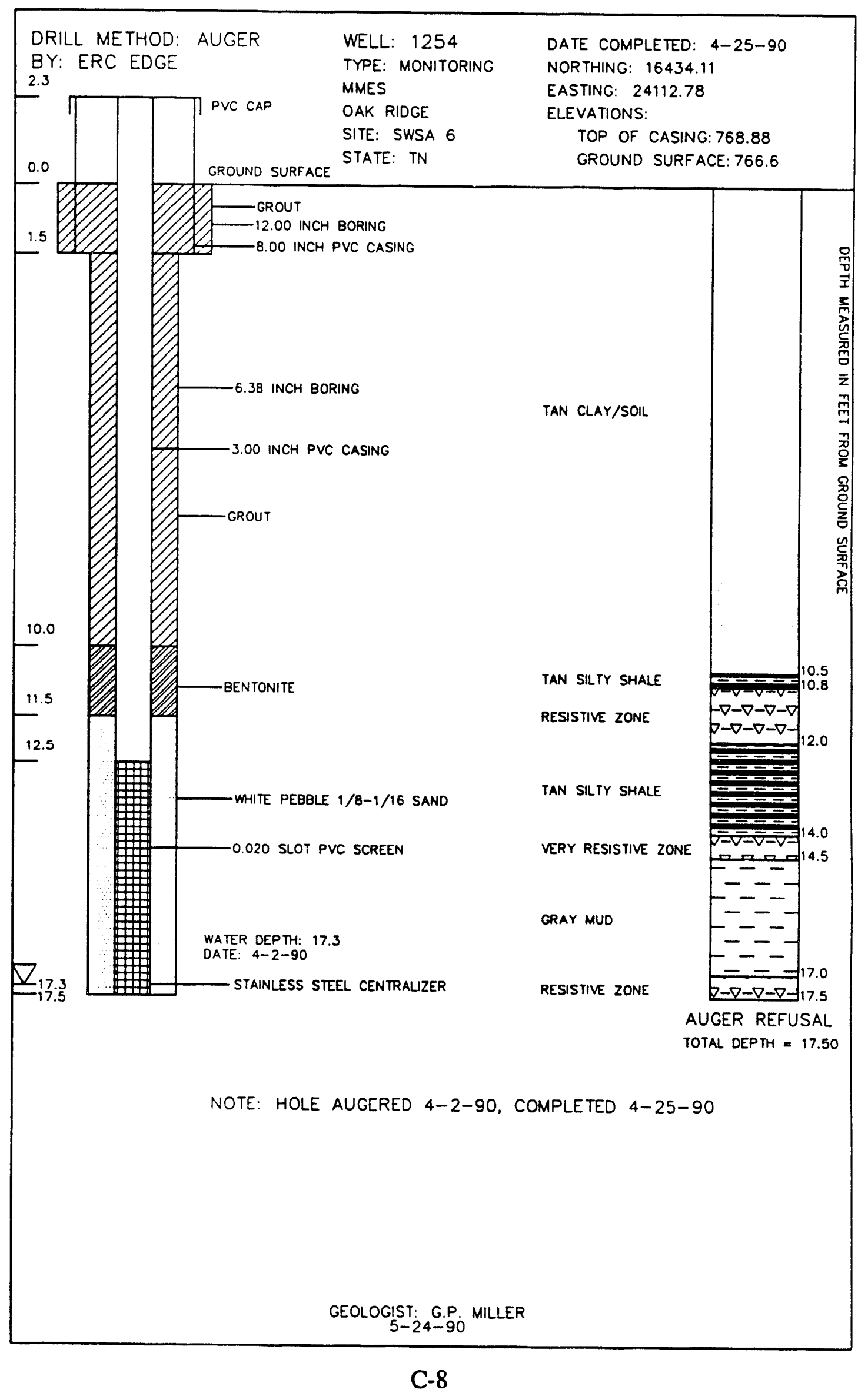




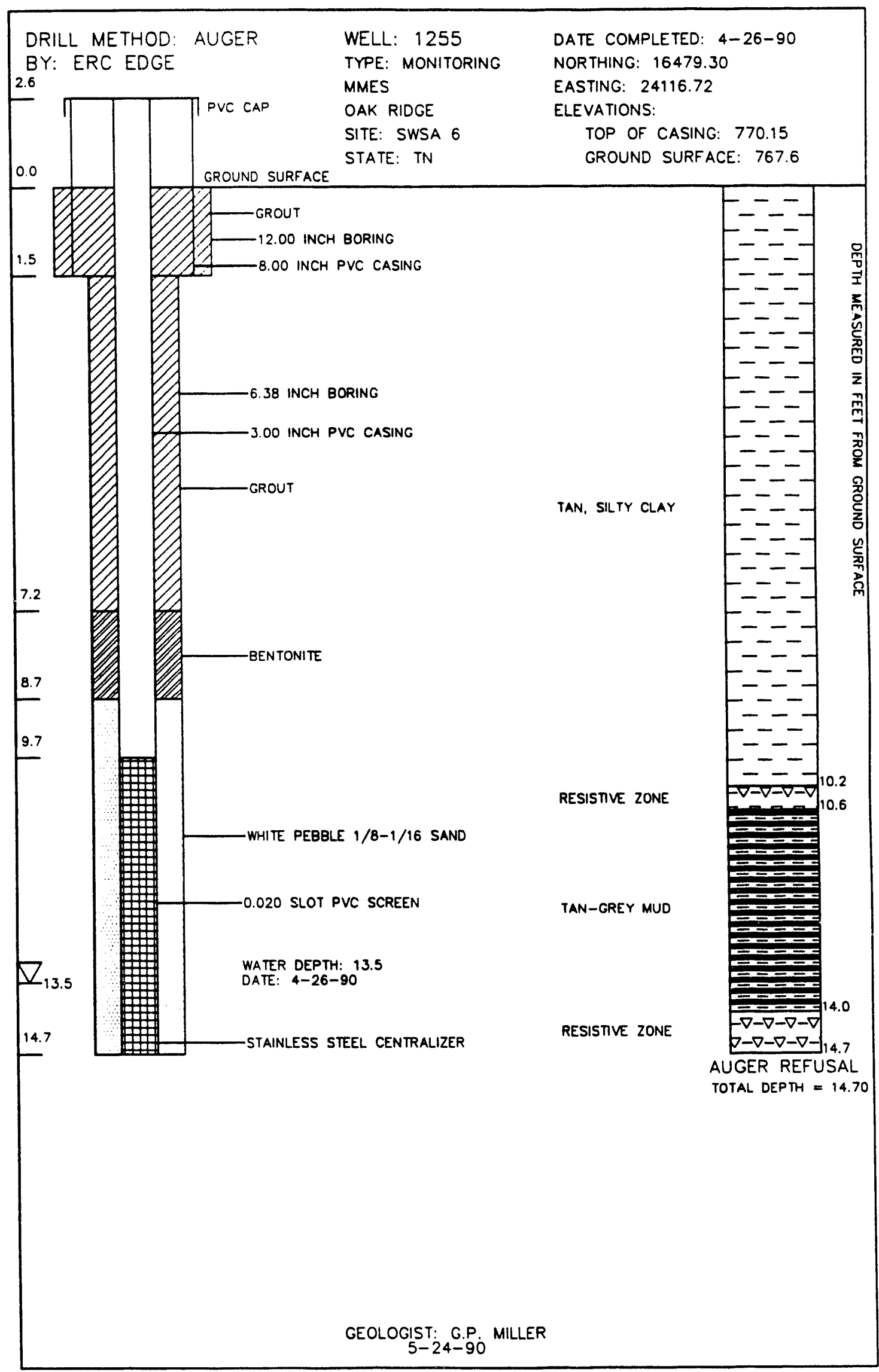

C-9 


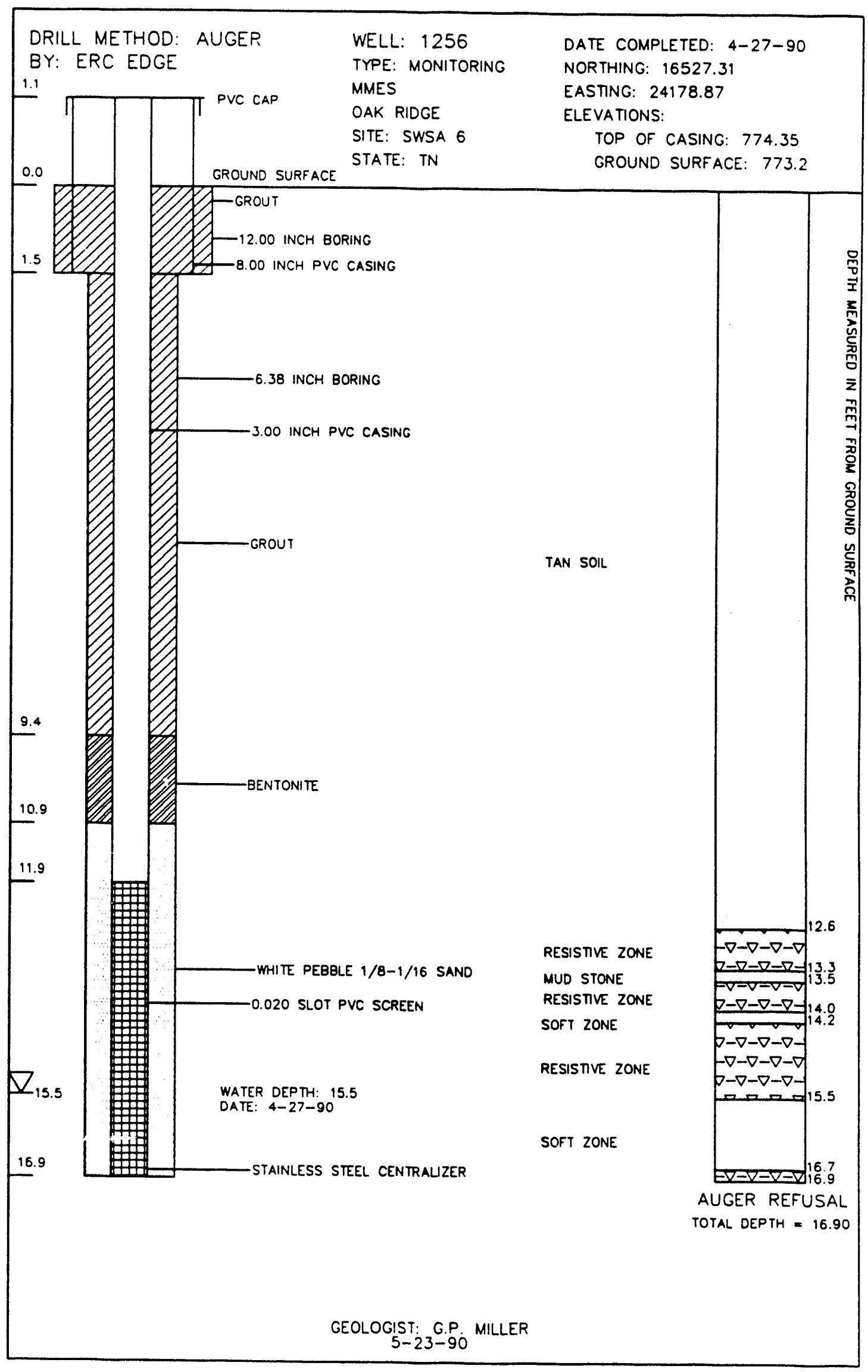

C-10 


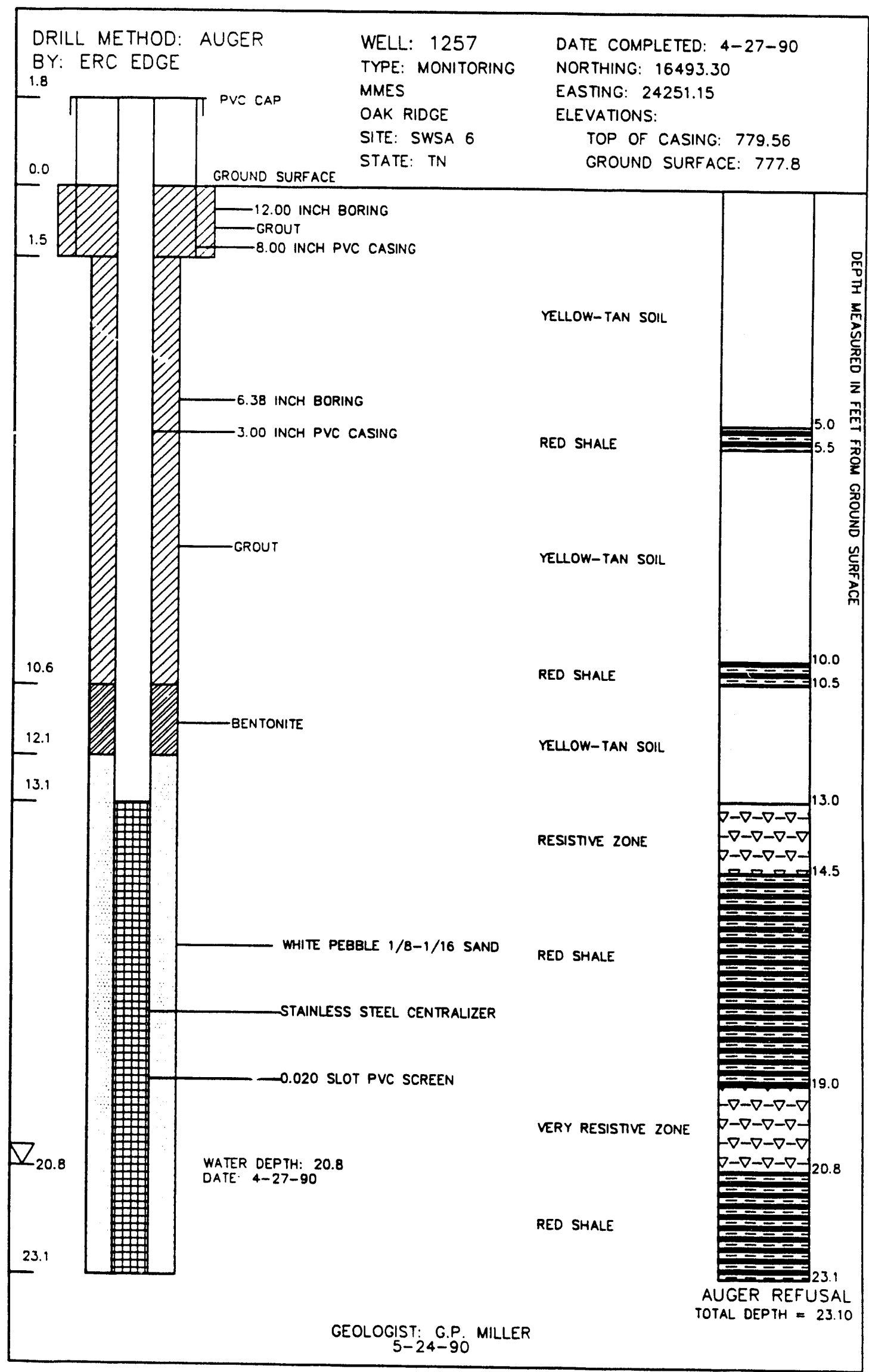

C-11 


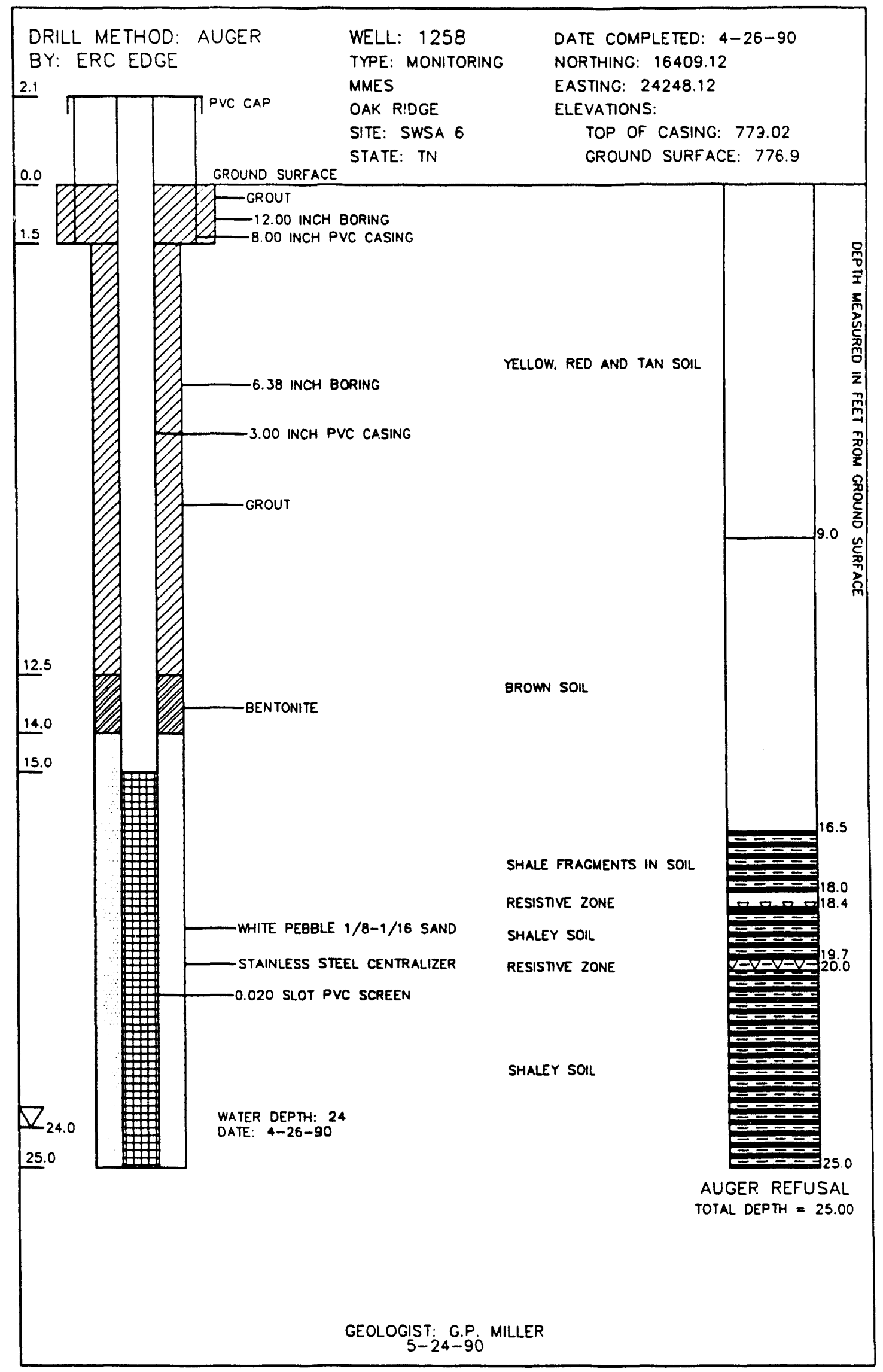

C-12 


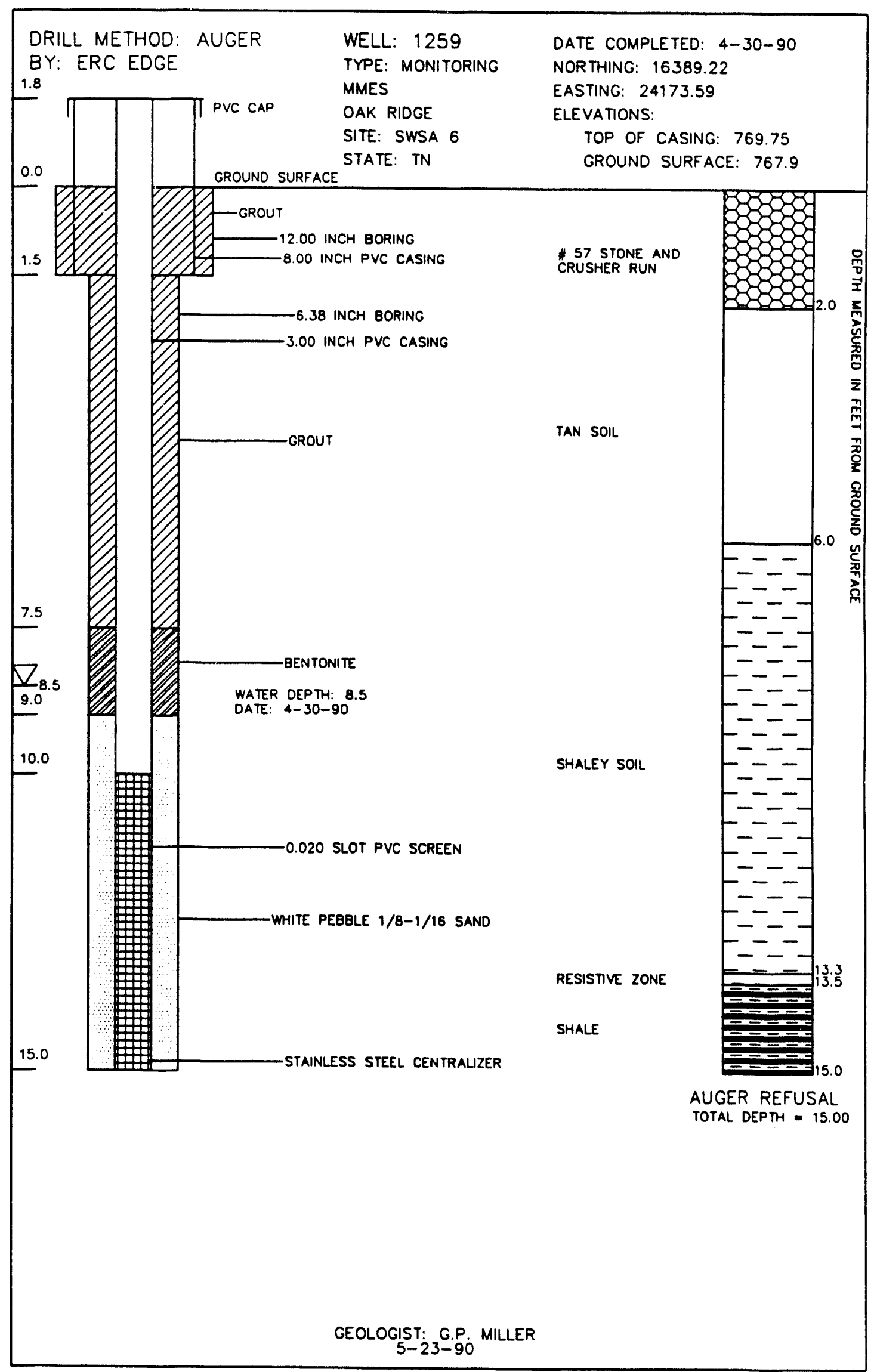

C-13 


\section{INTERNAL DISTRIBUTION}

1. H. L. Adair

2-6. T. L. Ashwood

7. F. P. Baxter

8. D. M. Borders

9. H. L. Boston

10. R. B. Clapp

11. T. O. Early

12. C. J. Ford

13. C. W. Francis

14. D. F. Hall

15. S. G. Hildebrand

16. D. D. Huff

17. C. A. Manrod

18. B. C. McClelland

19. W. M. McMaster

20. L. E. McNeese

21-25. C. M. Morrissey

26. J. B. Murphy
27. C. E. Nix

28. T. F. Scanlan

29. S. H. Stow

30. D. W. Swindle

31. J. R. Trabalka

32. J. E. Van Cleve

33. S. D. Van Hoesen

34. L. D. Voorhees

35. J. W. Wade

36. J. A. Watts

37. C. Whitmire, Jr.

38-48. D. S. Wickliff

49. Central Research Library

50-61. ESD Library

62-63. Laboratory Records Dept.

64. Laboratory Records, ORNL-RC

65. ORNL Patent Section

66. ORNL Y-12 Technical Library

\section{EXTERNAL DISTRIBUTION}

67. J. F. Franklin, Bloedel Professor of Ecosystem Analysis, College of Forest Resources, University of Washington, Anderson Hall (AR-10), Seattle, WA 98195

68. G. M. Hornberger, Professor, Department of Environmental Sciences, University of Virginia, Charlottesville, VA 22903

69. G. Y. Jordy, Director, Office of Program Analysis, Office of Energy Research ER-30, G-226, U.S. Department of Energy, Washington, DC 20545

70. R. H. Olsen, Vice President for Research, University of Michigan, Medical Science Building II, \#5605, 1301 East Catherine Street, Ann Arbor, MI 48109-0620

71. A. Patrinos, Acting Director, Environmental Sciences Division, Office of Health and Environmental Research, ER-74, U.S. Department of Energy, Washington, DC 20585

72. F. J. Wobber, Environmental Sciences Division, Office of Health and Environmental Research, ER-74, U.S. Department of Energy, Washington, DC 20585

73. Office of Assistant Manager for Energy Research and Development, Oak Ridge Operations, P.O. Box 2001, U.S. Department of Energy, Oak Ridge, TN 37831-8600

74-83. Office of Scientific and Technical Information, P.O. Box 62, Oak Ridge, TN 37831 

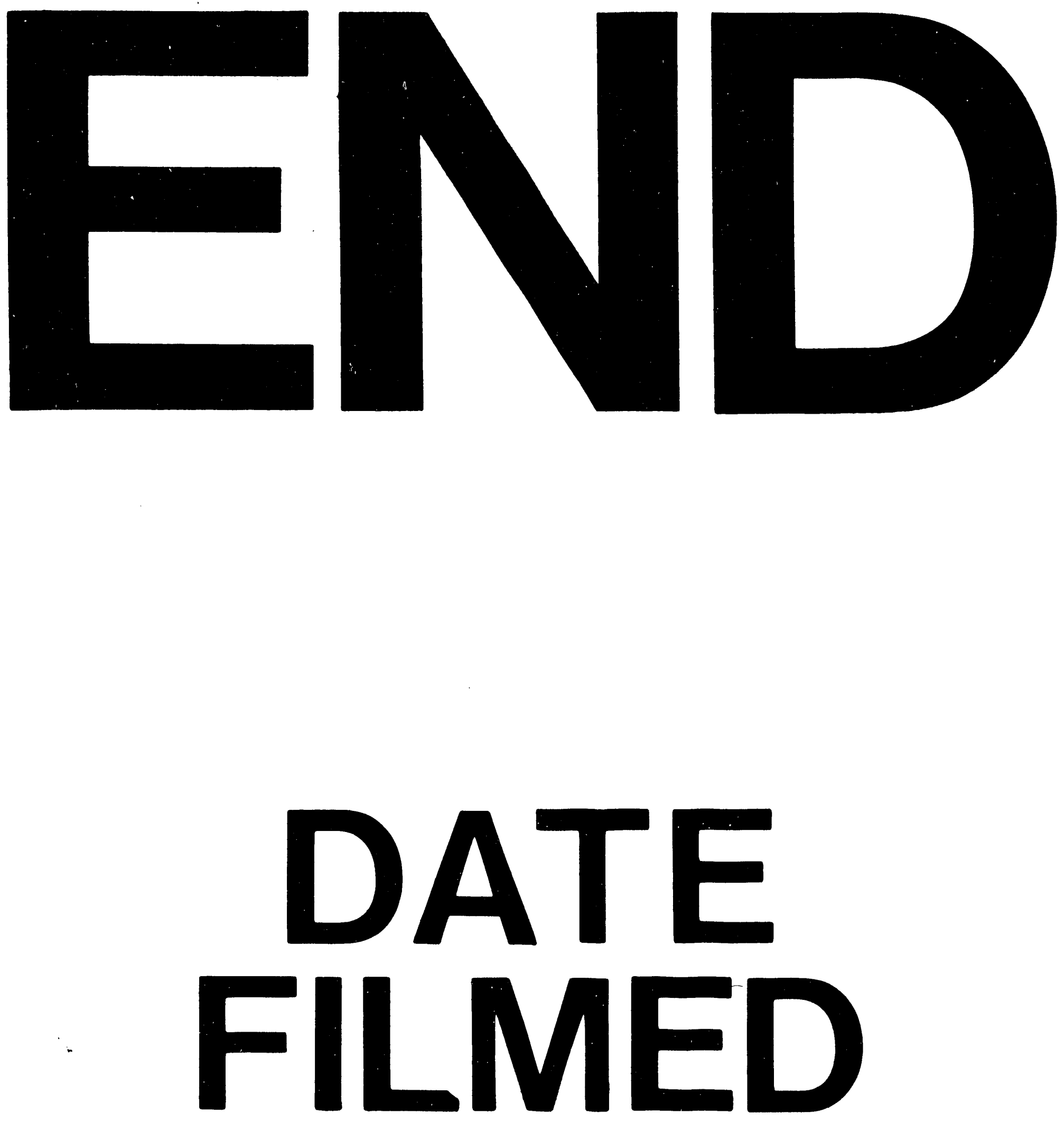

1

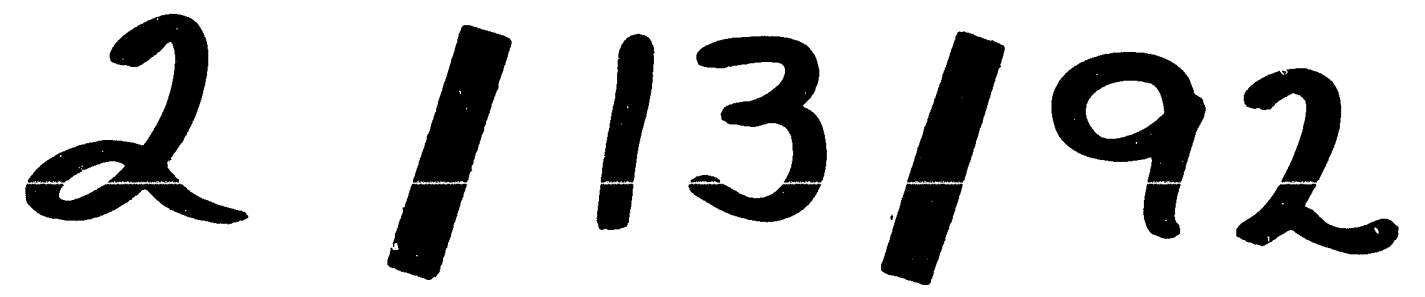


